\title{
scripted
}

Volume 20, Issue 1, February 2023

\section{The Right to Repair: Patent Law and 3D Printing in Australia}

\author{
Matthew Rimmer* \\ (ㄷ) (1) $\circledast \circledast$ \\ (C) 2023 Matthew Rimmer \\ Licensed under a Creative Commons Attribution-NonCommercial- \\ NoDerivatives 4.0 International (CC BY-NC-ND 4.0) license
}

DOI: $10.2966 /$ scrip.200123.130

\begin{abstract}
Considering recent litigation in the Australian courts, and an inquiry by the Productivity Commission, this paper calls for patent law reform in respect of the right to repair in Australia. It provides an evaluation of the decision of the Full Court of the Federal Court in Calidad Pty Ltd $v$ Seiko Epson Corporation [2019] FCAFC 115 - as well as the High Court of Australia consideration of the matter in Calidad Pty Ltd $v$ Seiko Epson Corporation [2020] HCA 41. It highlights the divergence between the layers of the Australian legal system on the topic of patent law - between the judicial approach of the Federal Court of Australia and the Full Court of the Federal Court of Australia, and the endorsement of the patent exhaustion doctrine by the majority of the High Court of Australia. In light of this litigation, this paper reviews the policy approach taken by the Productivity Commission in respect of patent law, the right to repair, consumer rights, and competition policy. After the considering the findings of the Productivity Commission, it is recommended that there is a need to provide for greater recognition of the right to repair under patent law. It also calls for the use of compulsory licensing, crown use, competition oversight, and consumer law protection to reinforce the right to repair under patent law. In the spirit
\end{abstract}


of modernising Australia's regime, this paper makes a number of recommendations for patent law reform - particularly in light of 3D printing, additive manufacturing, and digital fabrication. It calls upon the legal system to embody some of the ideals, which have been embedded in the Maker's Bill of Rights, and the iFixit Repair Manifesto. The larger argument of the paper is that there needs to be a common approach to the right to repair across the various domains of intellectual property - rather than the current fragmentary treatment of the topic. This paper calls upon the new Albanese Government to make systematic reforms to recognise the right to repair under Australian law.

\section{Keywords}

Patent law; patent validity; patent infringement; patent licensing; implied license; patent exhaustion; patent exceptions; crown use; compulsory licensing; competition policy; consumer protection law; the right to repair; 2D printing; 3D printing; additive manufacturing; digital fabrication; circular economy; sustainable development; Maker Movement; Maker's Bill of Rights; iFixit; iFixit Repair Manifesto

* Dr Matthew Rimmer (BA/LlB ANU, PhD UNSW) is a Professor in Intellectual Property and Innovation Law at the Faculty of Business and Law in the Queensland University of Technology (QUT). He is the chief investigator in the ARC Discovery Project, 'Inventing the Future: Intellectual Property and 3D Printing' (2017-2021) (DP 170100758). Earlier versions of this paper have been delivered at the Right to Repair Symposium at Griffith University in 2020; the Copyright Law and Creative Industries conference in 2020; Remaking the Maker Movement in 2021; and the BEST Conference in 2021. This paper has also been informed by engagement with the Productivity Commission inquiry into the right to repair. The author would also like to thank the editors, and the peer reviewers for their useful and helpful feedback on drafts of this paper. This article was submitted and accepted in 2020 - and has been updated before publication in 2023. 


\section{Introduction}

In Australia, there has been growing litigation and public policy debate over the right to repair. There have been increasingly conflicts between intellectual property owners and intellectual property users in respect of repairs.

The topic of the right to repair has arisen in a range of policy contexts. Andrew Leigh of the Australian Labor Party has complained of problems in respect of the right to repair in the field of motor vehicles. ${ }^{1}$ The Treasury of the Federal Government led by the Hon. Scott Morrison held an inquiry into the sharing of motor vehicle information for the purposes of repair. ${ }^{2}$ The West Australian National Party has called for the recognition of the right to repair for farmers. ${ }^{3}$ The Australian Competition and Consumer Commission (ACCC) is inquired into the right to repair and agricultural machinery. ${ }^{4}$ Moreover, the issue of the right to repair has also come up in discussions of product stewardship -

1 Andrew Leigh, 'Driving A Better Deal for Auto Dealers', Australia Automotive Dealer Associate Conference, Gold Coast Convention Centre, 4 September 2018, available at http://www.andrewleigh.com/driving_a better_deal_for_auto dealers (accessed 1 August 2021).

2 Treasury, 'Mandatory Scheme for the Sharing of Motor Vehicle Service and Repair Information: Consultation Paper' (2019), available at https://treasury.gov.au/consultation/c2019t358022 (accessed 1 August 2021); Matthew Rimmer, The Right to Repair: Mandatory Scheme for the Sharing of Motor Vehicle Service and Repair Information (Treasury 2019), available at https://eprints.qut.edu.au/127446/ (accessed 1 August 2021); Leanne Wiseman, Kanchana Kariyawasasm, and Lucas Davey, 'The Mandatory Repair Scheme for Motor Vehicles 2019: Australia's First Response to the International Right to Repair Movement?' (2020) 48 Australian Business Law Review 218; Hon. Michael Sukkar, 'Second Reading Speech on the Competition and Consumer Amendment (Motor Vehicle Service and Repair Information Sharing Scheme) Bill 2021' (Hansard, House of Representatives, Parliament of Australia, 24 March 2021), 7, available at

https://parlinfo.aph.gov.au/parlInfo/search/display/display.w3p;query=Id\%3A\%22chamber\%2Fhansar dr\%2Fd64bba7e-9b55-427c-aef1-2c98b347651d\%2F0014\%22 (accessed 1 August 2021).

3 Jennie Bremmer, 'Nationals call for Consumer Rights to Repair Electronics', (The West Australian, 16 October 2018), available at https://thewest.com.au/business/agriculture/nationals-callfor-consumer-rights-to-repair-electronics-ng-b88991358z (accessed 1 August 2021).

4 Australian Competition and Consumer Commission, 'Agricultural Machinery Market Study' (2021), available at https://www.accc.gov.au/publications/agricultural-machinery-market-study-finalreport (accessed 1 January 2023). 
with the Product Stewardship Act 2011 (Cth). ${ }^{5}$ Shane Rattenbury - first as the ACT Minister for Justice and Minister for Consumer Affairs, and then later as the ACT Attorney-General - called on the Productivity Commission to conduct an inquiry into the right to repair. ${ }^{6}$ He called upon the Federal Government - as well as the States and Territories - to work in a collaborative approach to provide for a common framework to recognise the right to repair. In response, the Federal Government - led by the Hon. Scott Morrison - initiated a Productivity Commission inquiry into the right to repair. ${ }^{7}$ In 2022, the new Federal Government - led by the Hon. Anthony Albanese MP - has promised legislative action in respect of the right to repair. ${ }^{8}$

The topic of the right to repair cuts across the various fields of intellectual property. ${ }^{9}$ There have been conflicts over copyright law, technological protection measures, and the right to repair. ${ }^{10}$ Such tensions have been acute in a 'tethered

5 The Australian Earth Laws Alliance, 'Challenging Consumption and Planned Obsolescence', available at https://www.earthlaws.org.au/our-programs/challenging-consumption/planned-ob/ (accessed 1 August 2021).

6 Shane Rattenbury, 'Can We Fix It? Yes We Can. ACT secures National Agreement on a "Right to Repair"' (Greens, 30 August 2019), available at https://greens.org.au/act/news/can-we-fix-it-yeswe-can-act-secures-national-agreement-right-repair (accessed 1 August 2021).

7 The Hon. Josh Frydenberg, 'Right to Repair: Terms of Reference' (Productivity Commission, 29 October 2020), available at https://www.pc.gov.au/inquiries/completed/repair/terms-of-reference (accessed 1 January 2023)

8 Hon. Andrew Leigh, 'Keynote address to the Australian Repair Summit 2022, Canberra' (Treasury Portfolio, 5 August 2022), available at https://ministers.treasury.gov.au/ministers/andrewleigh-2022/speeches/keynote-address-australian-repair-summit-2022-canberra (accessed 1 January 2023)

9 Aaron Perzanowski, The Right to Repair: Reclaiming the Things We Own (CUP 2022).

10 Andy Sun, 'Blocking Repair or Fair Use of Software? The U.S. Perspectives on Anticircumvention', in Christopher Heath and Anselm Kamperman Sanders (ed.), Spares, Repairs and Intellectual Property Rights, (Kluwer Law International 2009), 105-124; Aaron Perzanowski and Jason Schultz, The End of Ownership: Personal Property in the Digital Economy (MIT Press 2016); Matthew Gault, 'Nintendo Threatens Repair Shop for Advertising Switch Mod Chip Installs' (Vice, 18 June 2020), available at https://vice.com/en_us/article/7kpxbb/nintendo-threatens-repair-shop-for-advertising-switch-modchip-installs (accessed 1 August 2021). 
economy. ${ }^{\prime 1}$ Australia's design laws have recognised a right to repair - and there has been litigation over the nature and scope of this spare parts exception. ${ }^{12}$ There have been similar questions elsewhere about the right to repair under designs law in the United Kingdom, ${ }^{13}$ and design patents in the United States. ${ }^{14}$ There has been a consideration of whether the larger interest in social welfare has been adequately addressed in designs law. ${ }^{15}$ There has been debate over trade mark law and the right to repair ${ }^{16}$ - most notably, in the context of recent litigation by Apple against a repair store in Norway. ${ }^{17}$ There has also been interest in the use

11 Chris Jay Hoofnagle, Aniket Kesari, and Aaron Perzanowski, 'The Tethered Economy' (2019) 87 (4) The George Washington Law Review 783.

12 Section 72 of the Designs Act 2003 (Cth); GM Global Technology Operations LLC v S.S.S. Auto Parts Pty Ltd [2019] FCA 97.

13 David Llewelyn and Veronica Barresi, 'Right Holders' Control over Repair and Reconditioning', in Christopher Heath and Anselm Kamperman Sanders (ed.), Spares, Repairs and Intellectual Property Rights, (Kluwer Law International 2009), 3-20. This chapter looks at the right to repair in the context of design law in the European Union and the United Kingdom.

14 Peter Menell and Ella Corren, 'Design Patent Law's Identity Crisis' (2021) Berkeley Technology Law Journal, available at https://www.law.berkeley.edu/wpcontent/uploads/2021/02/Menell_Corren_Symposium-Webpage 01-29-21.pdf (accessed 1 August 2021); Joshua Sarnoff, 'Design Patents are Theft, Not Just A "Fraud on the Public," Who Need Legislation to Restore Their Repair Rights' (2021) Berkeley Technology Law Journal, available at https://www.law.berkeley.edu/wp-content/uploads/2021/02/Sarnoff-Berkeley-Tech.-L.J.-SpecialIssue Template-draft-02-18-21.pdf (accessed 1 August 2021).

15 Alison Firth, 'Repairs, Interconnections, and Consumer Welfare in the Field of Design', in Christopher Heath and Anselm Kamperman Sanders (ed.), Spares, Repairs and Intellectual Property Rights, (Kluwer Law International 2009), 147-180.

16 Michael Pendleton, 'Trademarks and Reconditioned Goods in Greater China and at Common Law', in Christopher Heath and Anselm Kamperman Sanders (ed.), Spares, Repairs and Intellectual Property Rights, (Kluwer Law International, 2009), 127-146.

17 Huseby $v$ Apple Inc., HR-2020-1142-A, Norway Supreme Court https://assets.documentcloud.org/documents/6936580/Norway.pdf (accessed 1 August 2021); For commentary, see Karl Bode, 'Norway Supreme Court Signs Off On Apple's Harassment Of An Independent Repair Shop (TechDirt, 5 June 2020), available at https://www.techdirt.com/articles/20200604/11170944646/norway-supreme-court-signs-off-applesharassment-independent-repair-shop.shtml (accessed 1 August 2021); Maja van der Velden, 'We all lose in the Case that Apple Won' (Blogging for Sustainability, 17 July 2019), available at https://www.smart.uio.no/blog/we-all-lose-in-the-case-that-apple-won.html (accessed 1 August 2021); Ole-Andreas Rognstad, 'Revisiting the Concept of Trade Mark Piracy in light of Sustainable Development Goals: a Discussion of the Norwegian Apple Case' in Ole-Andreas Rognstad and Inger B. Ørstavik (ed.), Intellectual Property and Sustainable Markets, (Edward Elgar, 2021), 101-114. 
of labelling schemes and certification trade marks to boost repair. ${ }^{18}$ There has been discussion in a range of jurisdictions about how the patent system deals with patent infringement and the right to repair. There has increasingly also been conflict over trade secrets and data protection related to repair. ${ }^{19}$

The focus of this paper is squarely on Australian patent law and the right to repair. In its inquiry, the Productivity Commission acknowledges that there have been conflicts over patent law and the right to repair - but is reluctant to make further recommendations for law reform. ${ }^{20}$ In response, this paper makes the case for substantive patent law reform in respect of the right to repair. In particular, it maintains that there should be a patent defence, which recognises the right to repair. The larger argument of the paper is that there needs to be a common approach to the right to repair across the various domains of intellectual property - rather than the current fragmentary treatment of the topic. It is problematic that, while repair may be protected under designs law, it is vulnerable to infringement actions under other domains of intellectual property law - such as copyright law, patent law, trade mark law, and trade secrets law. In its final report, the Productivity Commission mainly makes law reform recommendations in relation to copyright law, technological protection measures, and the right to repair. ${ }^{21}$ This paper maintains that there needs to be consistent reforms on the right to repair across all the fields of intellectual

18 Jay Sanderson and Teddy Henriksen, ‘Certified Repairable: Using Trade Marks to Distinguish, Signal and Encourage Repair' (2020) 31 Australian Intellectual Property Journal 161.

19 Treasury (n 2); Competition and Consumer Amendment (Motor Vehicle Service and Repair Information Sharing Scheme) Act 2021 (Cth); Sukkar (n 2).

20 Productivity Commission, 'Right to Repair: Draft Report' (Productivity Commission, 2021), available at https://www.pc.gov.au/inquiries/current/repair/draft (accessed 1 August 2021); Productivity Commission, 'Right to Repair: Inquiry Report No. 97' (Productivity Commission, 2022), available at https://www.pc.gov.au/inquiries/completed/repair/report (accessed 1 January 2023).

21 Productivity Commission, 'Right to Repair: Inquiry Report No. 97' (n 20). 
property - not just copyright. If there is not a uniform approach to the right to repair, there needs to be better harmonisation to the topic between the spheres of intellectual property law.

This paper argues that the need for a right to repair under intellectual property law is further accentuated by the advent of new technologies, such as 3D printing, digital fabrication, and additive manufacturing. This paper contends that there is a need for a holistic approach to patent law reform in light of 3D printing, digital fabrication, and additive manufacturing. At present, there is formal recognition of a right to repair in designs law. However, this defence is awkward and cumbersome and may well need to be updated and modernized in light of the development of new technologies. Moreover, given the crosscutting nature of 3D printing, other regimes of intellectual property (besides designs law) also need to establish and recognise a right to repair. There is a need for a substantive right to repair under the various species of intellectual property - including patent law. There is a need to ensure that the patent law enables citizens, consumers, makers, and companies to repair their own products (as has been recognised in the Maker's Bill of Rights and the Repair Manifesto). ${ }^{22}$ The Maker Movement has a strong ethos of fixing, and repairing broken inventions. ${ }^{23}$

22 Phillip Torone, 'Maker's Bill of Rights' (2006) Make Magazine, available at https://makezine.com/2006/12/01/the-makers-bill-of-rights/ (accessed 1 August 2021); TechCrunch, 'The Self-Repair Manifesto' (TechCrunch, 10 November 2010), available at https://techcrunch.com/2010/11/09/the-self-repair-manifesto/ (accessed 1 August 2021); iFixit, 'Repair Manifesto', available at https://www.ifixit.com/Manifesto (accessed 1 August 2021)

23 On the Maker Movement, see Chris Anderson, Makers: The New Industrial Revolution (Random House LLC 2012); Mark Hatch, The Maker Movement Manifesto: Rules for Innovation in the New World of Crafters, Hackers, and Tinkerers (McGraw-Hill Books 2013); Dale Dougherty with Ariane Conrad, Free to Make: How the Maker Movement is Changing our Schools, Our Jobs, and Minds (North Atlantic Books 2016); Neil Gershenfeld, Alan Gershenfeld and Joel CutcherGershenfeld, Designing Reality: How to Survive and Thrive in the Third Digital Revolution (Basic Books 2017); Mark Hatch, The Maker Revolution: Building a Future on Creativity and Innovation in an Exponential World (John Wiley \& Sons 2018). 
The topic of the right to repair brings into relief in a range of interests and concerns in the patent regime, highlighting tensions between underlying philosophical objectives. In terms of its conception of 'economic well-being', the patent regime seems to take a very traditional vision of economic growth and progress. The patent system should be responsive to the imperatives of promoting consumer rights and competition policy. However, there is an increasing problem with planned obsolescence - in which companies encourage a throwaway culture. ${ }^{24}$ There is a need for the patent regime to better reflect the need to develop a circular economy - in which there is sustainable production and consumption. ${ }^{25}$ In light of such concerns, there is a need to broaden our conception of the public interest objectives being promoted by Australia's patent regime. 'Economic well-being' does need to embrace consumer rights, competition policy, and social welfare. Moreover, there is a need to ensure that Australia's patent regime promotes sustainable development - particularly in terms of the reduction of waste, the development of responsible consumption and production, and the creation of a circular economy.

This paper considers the patent law and right to repair in the context of $2 \mathrm{D}$ printing and $3 \mathrm{D}$ printing. The main geographical focus of the paper is Australia - although there are comparisons made to other key jurisdictions. Part 2 looks at patent infringement, patent exhaustion, and the operation of the implied licence. In particular, it examines the patent litigation over 2D printing and refills between Seiko Epson Corporation and Calidad Pty Ltd - which has progressed through the Federal Court of Australia, the Full Court of the Federal

24 David R. Boyd, The Optimistic Environmentalist: Progressing Towards a Greener Future (ECW Press 2015), 51-67.

25 Kyle Wiens, 'Intellectual Property is Putting Circular Economy in Jeopardy' (The Guardian, 3 June 2014), available at https://www.theguardian.com/sustainable-business/intellectual-propertycircular-economy-bmwapple? $\mathrm{CMP}=$ share btn tw (accessed 1 August 2021). 
Court of Australia, and the High Court of Australia. This paper prefers the approach taken by the majority of the High Court of Australia - which focuses on patent exhaustion. Part 3 considers options for patent law reform in respect of the development of defence in respect of a right to repair; compulsory licensing; crown use or government use; oversight through competition law; and the recognition of the right to repair under contract law. Part 4 focuses upon the emerging challenges under Australian patent law in respect of 3D printing, additive manufacturing, and digital fabrication. It calls upon the legal system to embody some of the ideals, which have been embedded in the Maker's Bill of Rights, and the iFixit Repair Manifesto. Such law reform in respect of the right to repair is particularly important to help progress a circular economy in Australia. ${ }^{26}$

\section{Patent Infringement, Patent Exhaustion, and the Implied Licence}

There has been academic and judicial discussion about whether repair and recycling could constitute direct patent infringement. ${ }^{27}$ There has also been debate about whether repair and refill could amount to indirect patent infringement. ${ }^{28}$ There have been a variety of approaches taken to the question of patent infringement across different jurisdictions.

A distinction has been drawn in some jurisdictions between repairs and reconstruction in the discussion of patent infringement. In the United States, a

26 Productivity Commission, 'Right to Repair: Inquiry Report No. 97' (n 20).

27 Mineko Mohri, 'Repair and Recycle as Direct Patent Infringement?' in Christopher Heath and Anselm Kamperman Sanders (ed.), Spares, Repairs and Intellectual Property Rights (Kluwer Law International 2009), 59-84.

28 Christopher Heath, 'Repair and Refill as Indirect Patent Infringement', in Christopher Heath and Anselm Kamperman Sanders (ed.), Spares, Repairs and Intellectual Property Rights (Kluwer Law International 2009), 85-102. 
distinction is drawn between permissible repair of a patented article, and impermissible reconstruction of a patented article, which is patent infringement. In the classic 1961 and 1964 cases of Aro Manufacturing Co. v Convertible Top Replacement Co., the Supreme Court of the United States developed the United States doctrine on repair and reconstruction. ${ }^{29}$ The 1961 opinion emphasized:

\begin{abstract}
The decisions of this Court require the conclusion that reconstruction of a patented entity, comprised of unpatented elements, is limited to such a true reconstruction of the entity as to "in fact make a new article," after the entity, viewed as a whole, has become spent. In order to call the monopoly, conferred by the patent grant, into play for a second time, it must, indeed, be a second creation of the patented entity. ...Mere replacement of individual unpatented parts, one at a time, whether of the same part repeatedly or different parts successively, is no more than the lawful right of the owner to repair his property. Measured by this test, the replacement of the fabric involved in this case must be characterized as permissible "repair," not "reconstruction." 30
\end{abstract}

In the case of Jazz Photo $v$ U.S., the Court of Appeals for the Federal Circuit considered the repair and reconstruction doctrine, once again. ${ }^{31}$ The court found in favour of Jazz Photo: 'While there is no bright-line test for determining whether a device has been permissibly repaired, it does not turn on minor details.' ${ }^{32}$ The court held: 'We thus discern no error in the court's conclusion that those 'various minor operations' did not make a new single use camera and thus

\footnotetext{
29 Aro Manufacturing Co. v Convertible Top Replacement Co., 365 U.S. 336 (1961) (Aro 1); and Aro Manufacturing Co. v Convertible Top Replacement Co., 377 U.S. 476 (1964) (Aro 2).

30 Aro Manufacturing Co. v Convertible Top Replacement Co., 365 U.S. 336 (1961) (Aro 1).

31 Jazz Photo v U.S. (Fed. Cir. 2006, 05-1096).

32 Ibid.
} 
constituted permissible repair' ${ }^{33}$ There has been a growing secondary literature around the topic of intellectual property and the right to repair in the United States. ${ }^{34}$

In the United Kingdom, in the case of Schütz (U.K.) Limited v Werit (UK) Limited, the Supreme Court considered the relationship between patent law and repairs. ${ }^{35}$ The judge held that there was not patent infringement: 'In the present case, given that... apart from replacing it, Delta does no additional work to the article beyond routine repairs, I am of the view that, in carrying out this work, Delta does not "make" the patented article'. ${ }^{36}$ The judge noted 'that, while one's focus in a case such as this should not be deflected from the central question of whether the alleged infringer "makes" the patented article, it may sometimes be a useful cross-check to consider whether its activities involve repairing the original product.' 37 The judge observed that as, 'Delta does not "make" a new patented article, I am of the view that its cross-bottling activities involve repairing the original product.' ${ }^{38}$

In Australia, there has recently been a discussion of patent law and the right to repair in the context of ink refills for $2 \mathrm{D}$ computer printers. There has been an analysis of patent infringement in this context. There has also been discussion about the operation of an implied licence in respect of the right to repair. The question of repair has also raised larger considerations in respect of first sale and patent exhaustion.

33 Ibid.

34 Leah Chan Grinvald and Ofer Tur-Sinai, 'Intellectual Property Law and the Right to Repair' (2019) 88 Fordham Law Review 63; Leah Chan Grinvald and Ofer Tur-Sinai, 'The Right to Repair: Perspectives from the United States' (2020) 31 Australian Intellectual Property Journal 98; Aaron Perzanowski, 'Consumer Perceptions of the Right to Repair' (2021) 96 (2) Indiana Law Journal 361.

35 Schütz (UK) Ltd v Werit (UK) Ltd [2013] UKSC 16.

36 Ibid.

37 Ibid.

38 Ibid. 


\subsection{Federal Court of Australia}

In the 2017 case of Seiko Epson Corporation v Calidad Pty Ltd, Burley J of the Federal Court of Australia noted: 'In the fiercely competitive world of computer printers and ink refills for those printers, the first applicant, Seiko Epson Corporation (Seiko) is a global player.' ${ }^{39}$ Ninestar Image (Malaysia) SDN bought empty cartridges and refilled them with ink, and then sold them to Calidad Distributors Pty Ltd (CDP).

The judge held that 'the central dispute in these proceedings concerns the right of a patentee to control or limit what may be done with a patented product after it has been sold. ${ }^{\prime 0}$ There is a tension identified between property law and intellectual property law. The judge observed: 'This gives rise to consideration of the intersection of the general rights of property ownership in a chattel once sold, and the monopoly rights conferred on a patentee under the Patents Act 1990 (Cth). ${ }^{41}$ The judge explored the question: 'When a patentee sells a chattel that embodies an invention claimed in a patent, can the patentee restrain the subsequent use made of it by a purchaser or a successor in title to the purchaser? ${ }^{42}$

Calidad submitted that a patentee's exclusive rights under s 13(1) of the Patents Act 1990 (Cth) do not include the right to prevent the owner repairing or refurbishing a patented product, or have subsequent dealings in that repaired or refurbished product (including importation). The judge considered at length some of the United Kingdom authorities on patent law and the right to repair. In the end, Burley J held: 'Applying the principles set out in that case, I have found

\footnotetext{
9 Seiko Epson Corporation v Calidad Pty Ltd [2017] FCA 1403 [1].

40 Ibid [2].

41 Ibid [2].

42 Ibid [2].
} 
that Seiko's infringement claim succeeds for Calidad's past range of products, but not in respect of its current products.' ${ }^{43}$

The case also involved some secondary questions in respect of trade mark law and consumer law as well. The judge concluded that the impugned use was not use of the word Epson in a trade mark sense and that the cause of action is not made out. The judge also held that the action for misleading and deceptive conduct was not made out. This secondary dispute highlights that Australian trade mark law needs to also recognise the right of repair. ${ }^{44}$ Likewise, Australian consumer law should also be supportive of repair.

\subsection{Full Federal Court}

In the 2019 case of Calidad Pty Ltd v Seiko Epson Corporation [2019] FCAFC 115, the Full Court of the Federal Court of Australia heard an appeal. ${ }^{45}$

\subsubsection{Greenwood J}

Summarising the issue at stake, Greenwood J observed: 'These proceedings raise an important question concerning the extent to which a patentee... can prevent a person who has acquired title to a patented product... from, put simply for present purposes, manipulating or "repurposing" (as it is described) the patented product for subsequent sale.' 46

Greenwood J also observed that the matter raised larger questions about the approach taken in Australia to patent exhaustion - especially as compared to

43 Ibid [4].

44 There has also been a number of comparative trade mark disputes over repair - see in Norway, Huseby $v$ Apple Inc. (n 17); in South Africa, Bayerische Motoren Werke Aktiengesellschaft v Grandmark International (722/12) [2013] ZASCA 114; and in the United States, Toyota Motor Sales USA Inc v Tabari, $610 \mathrm{~F} 3 \mathrm{~d} 1171$ (9th Cir, 2010).

45 Calidad Pty Ltd $v$ Seiko Epson Corporation [2019] FCAFC 115.

46 Ibid. 
United States Supreme Court authorities. ${ }^{47}$ The judge referred to a range of United States precedents in the course of his judgment. ${ }^{48} \mathrm{~A}$ traditionalist by inclination, Greenwood J was reluctant to follow such precedents because of a belief that Australian patent law was derived from British authorities, rather than United States precedents: 'It would not be appropriate to embark upon any consideration of that doctrine or the foundation principles developed by the United States Supreme Court which caused their Honours, in that country, to adopt it as an appropriate position in the patent law of the United States for the citizens of that country. ${ }^{49}$ His Honour observed that 'the question of whether an exhaustion of rights doctrine is to form part of the patent law of Australia on behalf of the citizens of this country is a matter to be determined by the High Court of Australia in the discharge of its role as the highest court of appeal at the apex of the Australian appellate structure, assuming their Honours grant special leave to appeal in the relevant class of case. ${ }^{50}$ Greenwood J was concerned that the adoption of United States precedents by a Federal Court judge would be a radical departure from the established jurisprudence - especially given the hierarchical supremacy of the High Court of Australia.

The judge considered the relevance of a 1911 decision of the Privy Council and a 1908 decision of the High Court of Australia. ${ }^{51}$ Greenwood J considered the nature and scope of an implied licence:

47 Ibid.

48 Impression Products Inc v Lexmark International Inc., 137 S. Ct. 1523 (2017); United States v Univis Lens Co. US 241 (1942); Quanta Computer, Inc., v LG Electronics, Inc., 553 US 617 (2008); Kirtsaeng $v$ John Wiley \& Sons Inc., 568 US 519 (2013); Boston Store of Chicago v American Graphophone Co., [1918] USSC 42; 246 US 8 (1918); United States v General Elec. Co., [1926] USSC 211; 272 US 476 (1926).

49 Calidad Pty Ltd v Seiko Epson Corporation (n 45) [10].

50 Ibid [9].

51 National Phonograph Company of Australia Limited v Menck [1911] UKPCHCA 1; National Phonograph Company of Australia Limited v Menck [1908] HCA 96. 
The scope of the implied licence, however, does not include a right to 'make' the product being a right exclusively reserved to the patentee. The 'owner' of a product, where the invention defined by a claim or claims, is that product, does not enjoy, by reason of ownership, a right to make an infringing product. ${ }^{52}$

Greenwood J held: 'Calidad's entitlement to import the modified product so described above rises no higher than the limitations in the implied licence relating to Ninestar's conduct.' ${ }^{53}$ Greenwood J observed: CDP has imported into Australia for sale, kept for sale, offered for sale and sold, a product which does not fall within the scope and content of the implied licence.' ${ }^{54}$ Greenwood J concluded: 'Calidad has thus infringed Seiko's patents.' 55

\subsubsection{Jagot $J$}

In a separate judgment, Jagot J dismissed the appeal by Calidad:

The implied licence arising on Seiko's unrestricted sale of the printer cartridges did not extend to any of the modifications necessary to enable the cartridges to be re-used. The modifications did not amount to the repair of any cartridge. Rather, in each case, the totality of the modifications constituted the making of a new embodiment of the invention claimed in the patents. ${ }^{56}$

The judge emphasized that the modifications did not amount to the repair of the cartridge.

52 Calidad Pty Ltd $v$ Seiko Epson Corporation (n 45) 115.

53 Ibid.

54 Ibid.

55 Ibid.

56 Ibid. 
As part of the judgment, Jagot J considers the past precedents in respect of patent law and repair. The judge noted: 'Seiko is also right that the repair cases are able to be understood as involving an assessment of the scope of the implied licence which arises on unrestricted sale of a patented article. ${ }^{57}$ Jagot J cites Buckley LJ's remarks in the 1977 case of Solar Thompson Engineering Co Ltd $v$ Barton on the doctrine of repair in the context of the implied licence:

\begin{abstract}
It has long been recognised that a purchaser of a patented article may carry out repairs to it without being held liable for infringement. On the other hand he cannot manufacture a new article which infringes the patent and claim that he has not infringed merely because in the manufacture he has used parts derived from a patented article sold by the patentee. ${ }^{58}$
\end{abstract}

The judge cites an array of United Kingdom authorities considering the difference between a repair and making a new article. ${ }^{59}$ Buckley LJ insisted: 'The cardinal question must be whether what has been done can fairly be termed a repair, having regard to the nature of the patented article.' 60

Jagot J also considered the approach of Aldous J in the 2001 case of United Wire Ltd $v$ Screen Repair Services (Scotland) Ltd that the 'concept of a licence ... is not really applicable to the repair of a patented article'. ${ }^{61}$ On appeal, Lord Hoffman approved this approach. Lord Hoffman cited Lord Halsbury L.C.'s remarks in the 1907 case of Sirdar Rubber Co. Ltd v Wallington, Weston E Co: "you

57 Ibid.

58 Solar Thompson Engineering Co Ltd v Barton [1977] RPC 537, 554 - cited in Calidad Pty Ltd $v$ Seiko Epson Corporation (n 45) 115.

59 Dunlop Pneumatic Tyre Co. Ltd. v Neal (1899) 16 RPC 247; Dunlop Pneumatic Tyre Co. Ltd. $v$ Holborn Tyre Co. Ltd. (1901) 18 RPC 222; Sirdar Rubber Co. Ltd v Wallington Weston \& Co. (1907) 24 RPC 539, 543.

60 Calidad Pty Ltd v Seiko Epson Corporation (n 45) 115.

61 United Wire Ltd $v$ Screen Repair Services (Scotland) Ltd [2001] RPC 24. 
may prolong the life of a licensed article but you must not make a new one under the cover of repair."'62

Jagot J held that 'Repair is one of the concepts (like modifying or adapting) which shares a boundary with "making" but does not trespass upon its territory.' ${ }^{63}$ Jagot $\mathrm{J}$ argued that 'in an action for infringement by making, the notion of an implied licence to repair is superfluous and possibly even confusing.' ${ }^{64}$ In the judge's view, [the discussion of repair] 'distracts attention from the question raised by section 60(1)(a), which is whether the defendant has made the patented product.' ${ }^{65}$ Jagot J was concerned about linguistic confusion, noting that 'As a matter of ordinary language, the notions of making and repair may well overlap' but for 'the purposes of the statute, they are mutually exclusive'. ${ }^{66}$ Jagot J held: 'The owner's right to repair is not an independent right conferred upon him by licence, express or implied.' ${ }^{67}$ Jagot J maintained: 'It is residual right, forming part of the right to do whatever does not amount to making the product.' 68

Jagot J also referred to Solar Thomson Engineering Co. Ltd v Barton, where the Court of Appeal held that there was an implied licence to repair. ${ }^{69}$ Jagot J noted: 'But the juridical nature of the right to repair was not in issue.' 70

The judge also cited the views of the 2013 case of Full Court of the Supreme Court of the United Kingdom in Schütz (UK) Ltd $v$ Werit (UK) Ltd: 'The mere fact that an activity involves replacing a constituent part of an article does not mean

62 Sirdar Rubber Co. Ltd v Wallington, Weston \& Co. (n 59) 543.

63 Calidad Pty Ltd v Seiko Epson Corporation (n 45) 115.

64 Ibid.

65 Ibid.

66 Ibid.

67 Ibid.

68 Ibid.

69 Solar Thomson Engineering Co. Ltd v Barton (n 58).

70 Calidad Pty Ltd v Seiko Epson Corporation (n 45) 115. 
that the activity involves "making" of a new article rather than constituting a repair of the original article'. ${ }^{71}$

The judge commented 'that a purchaser has no right to make a new embodiment of the invention.' 72 The judge observed:

The implied licence arising on unrestricted sale could never extend so far. Nor could the doctrine of exhaustion of patent rights result in the loss of the right to prevent the making of new embodiments of the invention, whether or not the new embodiment involved starting from scratch or re-using and modifying parts of the patented product as sold. ${ }^{73}$

The judge concluded: 'I do not consider any aspect of the present case lies at the "borderline" between repair and making. ${ }^{74}$

\subsubsection{Yates $J$}

Yates J commented that 'this appeal concerns the right of a patentee to control or limit what may be done with a patented product after it has been sold.' 75

In terms of the analysis of the case, Yates J deals directly with the question of the right to repair:

It is convenient to commence by addressing Calidad's submissions on the subject of repair and refurbishment. As I have remarked, Calidad's inclusion of a right of refurbishment appears to be an embellishment of the subject matter dealt with in the United Kingdom cases. So far as I can see, the United Kingdom cases speak only of a right of repair arising from an implied licence

71 Schütz (UK) Ltd v Werit (UK) Ltd (n35) - cited in Calidad Pty Ltd v Seiko Epson Corporation (n 45) 115.

72 Calidad Pty Ltd v Seiko Epson Corporation (n 45) 115.

73 Ibid.

74 Ibid.

75 Ibid. 
to repair or, more latterly, existing as a residual right falling outside the monopoly right to 'make' the patented article. ${ }^{76}$

The judge ruled: 'On no reasonable view can it be said that the modifications carried out by Ninestar to the original Epson cartridges constitute "repair". ${ }^{77}$ The judge held: 'The commencement of Calidad's argument in this regard is that the cartridges acquired by Ninestar no longer worked.' ${ }^{78}$ The judge maintained: 'The implication is that these cartridges were, somehow, "broken" and in need of repair so that they could continue to function as they were intended to function when first sold.' 79 The judge cautioned: 'To so view the cartridges would be a mischaracterisation of the facts of the case.' 80

Yates J held: 'Ninestar's modifications were not carried out to repair the cartridges, but to re-purpose them.' ${ }^{81}$ The judge explored whether there could be a 'right of refurbishment' - if not a 'right to repair' under Australian law:

Properly considered, Ninestar's modifications were not refurbishment, if 'refurbishment' is taken to be some form of remediation different to repair that is nevertheless required to rectify some defect or deficiency in the cartridges. The simple fact is that there was no defect or deficiency as such. By the time the original Epson cartridges reached Ninestar's hands, the purpose of their intended use had been achieved and their utility, as intended, was spent. Seiko programmed them to be that way. ${ }^{82}$

The judge commented that 'on the facts of the case, consideration of whether

76 Ibid.

77 Ibid

78 Ibid.

79 Ibid.

80 Ibid.

81 Ibid.

82 Ibid. 
Australian patent law recognises a right of repair, or for that matter a right of refurbishment, can be-and should be-put to one side.' ${ }^{83}$ Yates J commented: 'That question does not arise for consideration. ${ }^{84}$

Yates $\mathrm{J}$ held that the remanufacture of the cartridge went beyond the implied license in the case: 'It is sufficient for me to say that, in my view, the modifications amounted to remanufacture of the discarded original Epson cartridges to produce reborn printer cartridges that could not be said to have been of Seiko's making'. ${ }^{85}$ The collection of judgments show a cautious approach to the topic of the right to repair - recognising both the role of the High Court of Australia in interpreting the law, and the policy choices of the Australian Parliament in dealing with the topic.

The outcome of the decision may be somewhat dispiriting for consumers and citizens - as it would mean that they would have to pay more for secondary products for printers.

\subsection{The High Court of Australia}

In November 2019, the High Court of Australia agreed to hear an appeal in the matter of Calidad Pty Ltd $v$ Seiko Epson Corporation. ${ }^{86}$ Writing about the case, FB Rice patent attorneys Paul Whenman and Sarah Glasson hoped: 'Importantly, we think it is an opportunity for the High Court [of Australia] to recognise the importance of waste reduction and product design that permits product reuse. ${ }^{87}$

83 Ibid.

84 Ibid.

85 Ibid.

86 Calidad Pty Ltd $\mathcal{E}$ Ors $v$ Seiko Epson Corporation $\mathcal{E}$ Anor Case S329/2019, available at https://www.hcourt.gov.au/cases/case s329-2019 (accessed 1 August 2021).

87 Paul Whenham and Sarah Glasson, 'What Dead Parrots can tell us about Printer Cartridges' (Lexology, 20 May 2020), available at https://www.lexology.com/library/detail.aspx?g=0362ccfb198a-4eed-a57d-3f10d1425724 and https://s3.amazonaws.com/documents.lexology.com/7ca8d2cf7caf-4c40-a1ff- 
They observed: 'The Seiko Epson cartridges, prior to the Ninestar modifications, were not designed for reuse. ${ }^{88}$ Wheham and Glasson comment: 'In fact, nowhere in patent 2009233643 is there anything to suggest how the cartridges could be reused.' ${ }^{89}$ They observed:

Society is objectively moving towards products that are capable of repair and/or reuse. If innovators are content to obtain patents for products without any thought of repair and/or reuse, then the patent monopoly must be similarly limited in scope. It is simply untenable to believe otherwise. ${ }^{90}$

Wheham and Glasson comment: 'At this time, the High Court has a pivotal role to play in ensuring the patent system is in harmony with this societal objective. ${ }^{91}$ There has been a larger concern about the relevance of the right to repair to product design and obsolescence, managing e-waste, and the progress towards a circular economy..$^{92}$

\subsubsection{Written Argument}

In February 2020, the High Court of Australia received written submissions from the parties. In its appellants' submissions, Calidad commented: 'Stated generally, the issue presented by this appeal is whether, and if so, the extent to which, a patentee can control or limit what may be done with a patented product after it has been sold by or with the licence of the patentee. ${ }^{93}$ Calidad commented:

46f350271cd5.pdf?AWSAccessKeyId=AKIAVYILUYJ754JTDY6T \&Expires=1603865956\&Signatu

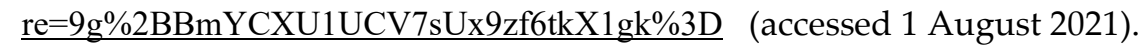

88 Ibid.

89 Ibid.

90 Ibid.

91 Ibid.

92 Productivity Commission, 'Right to Repair: Inquiry Report No. 97' (n 20).

93 Appellants' Submission in Calidad Pty Ltd $\mathcal{E}$ Ors $v$ Seiko Epson Corporation \& Anor Case S329/2019 https://cdn.hcourt.gov.au/assets/cases/08-Sydney/s329-2019/Calidad-SeikoEpson_App.pdf (accessed 1 August 2021). 
The first question is whether a doctrine of exhaustion of patent rights on first sale should be recognised. A second and related question is what that doctrine encompasses, if it is to be recognised. For the reasons outlined below, Calidad respectfully submits that the decision of the Privy Council in Menck should not be followed, and that the decision of this Court in NPCAL should be preferred. Seiko's patent rights in this case were exhausted by its sale of the original Epson cartridges. ${ }^{94}$

Calidad stressed: 'The resolution of those questions is important, because the adoption of an implied licence and analysis of its terms were central to the reasoning below.' 95

Calidad prefers the approach of the Supreme Court of the United States in the case of Impression Products v Lexmark ${ }^{96}$ in 2017: 'As submitted, this strikes an appropriate balance between the monopoly rights of a patentee, and principles of personal property and competition. ${ }^{97}$ Calidad cited the illustration of the Supreme Court of the United States in respect of a repair shop for cars - which stressed 'so long as those bringing in the cars own them, the shop is free to repair and resell those vehicles.' ${ }^{98}$

The respondents questioned the approach of Calidad to the issue of the right to repair. ${ }^{99}$ The respondents emphasized: ‘The cartridges were not broken or in need of repair; they had functioned in the manner intended upon sale and

94 Ibid.

95 Ibid

96 Impression Products, Inc v Lexmark International Inc (n 48).

97 Appellants' Submission in Calidad Pty Ltd $\mathcal{E}$ Ors $v$ Seiko Epson Corporation $\mathcal{E}$ Anor Case S329/2019 (n 93).

98 Ibid.

99 Respondents' Submission in Calidad Pty Ltd $\mathcal{E}$ Ors $v$ Seiko Epson Corporation $\mathcal{E}$ Anor Case S329/2019 https://cdn.hcourt.gov.au/assets/cases/08-Sydney/s329-2019/Calidad-SeikoEpson_Res.pdf (accessed 1 August 2021). 
purchase and, on that basis, had been "discarded" by the initial purchaser. ${ }^{\prime 00}$ The respondents maintained that Calidad had just repurposed the inventions.

\subsubsection{Oral Argument}

The progress of the case was be affected by the coronavirus COVID-19 outbreak in 2020. In the end, the High Court of Australia held a hearing on the $12^{\text {th }}$ August 2020. ${ }^{101}$ A number of judges - including Kiefel CJ, Edelman J, and Gageler J were particularly active, with their questions for counsel. There was much discussion of comparative approaches to patent exhaustion, implied licenses, and parallel importation. There was some heated discussion of patent law and repair. For the respondents, AJ Bannon explained to the court the nature of a 'repair':

If I may attempt to answer your Honour Justice Edelman's question again, the difference in repair is you are restoring it back to the condition it was in, in circumstances where it is spent or been damaged. What has happened here on any view is the creation of a new embodiment with two holes resealed by tape which can be reused for both outlet and inlet purposes. That is the difference. ${ }^{102}$

For the appellants, David Shavin QC commented: 'In relation to the making, in our respectful submission, our friends are ignoring all of the jurisprudence to which we went yesterday, which showed that "repair" has a very wide connotation and, as Lord Hoffmann said, it includes modification improvement.' ${ }^{\prime 03}$ The parties have made some supplementary submissions.

\footnotetext{
${ }^{100}$ Ibid 4.

${ }_{101}$ Calidad Pty Ltd \& Ors v Seiko Epson Corporation \& Anor [2020] HCATrans 107.

102 Ibid.

${ }^{103}$ Ibid.
} 
The High Court of Australia handed down its decision in November 2020 - which was a surprisingly quick turnaround from the oral proceedings. ${ }^{104}$ The final outcome was final balanced. The majority of the High Court of Australia Kiefel CJ, Bell and Keane JJ - overturned the previous rulings by the Federal Court of Australia and the Full Court of the Federal Court Australia. There was an additional judgment by Gageler J which supported the majority judgment. There was a minority judgment - consisting of Nettle, Gordon, and Edelman JJ.

\subsubsection{Majority Judgment of Kiefel CJ, Bell and Keane JJ}

The majority judgment of Kiefel CJ, Bell and Keane JJ considered at length past precedents dealing with patent law and repair. ${ }^{105}$

On the facts of the case, the judges observed: 'When all of Ninestar's modifications to each of the categories of cartridges were completed what remained were the original Epson cartridges with some modifications which enabled their re-use.' 106 The judgement stressed: 'The modifications did not involve the replication of parts and features of the invention claimed'. ${ }^{107}$ In their view, 'There was no true manufacture or construction of a cartridge which embodied the features of the patent claim.' 108 Kiefel, Bell, and Keane JJ concluded:

The modifications to the original Epson cartridges were consistent with the exercise of the rights of an owner to alter an article to improve its usefulness and enable its re-use. Both English ${ }^{109}$ and United States authority accept the

\footnotetext{
104 Calidad Pty Ltd v Seiko Epson Corporation [2020] HCA 41.

105 Ibid.

106 Ibid [69].

107 Ibid.

108 Ibid.

109 United Wire Ltd $v$ Screen Repair Services (Scotland) Ltd (n 61) 458-459, [70] per Lord Hoffmann, quoting Sirdar Rubber Co. Ltd v Wallington, Weston E Co. (n 59) 543.
} 
prolonging of the life of a product to be within an owner's rights of use of a patented product. Regardless of whether it is said to be something done which is closer to "repair" than "making", it clearly does not involve a manufacture or making. ${ }^{110}$

The majority judgment then considered whether the patent exhaustion doctrine or implied license theory would be the best explanation of this position.

Kiefel CJ, Bell and Keane JJ preferred to rely upon the patent exhaustion doctrine:

The exhaustion doctrine has the virtues of logic, simplicity and coherence with legal principle. It is comprehensible and consistent with the fundamental principle of the common law respecting chattels and an owner's rights respecting their use. At the same time, it does not prevent a patentee from imposing restrictions and conditions as to the use of a patented product after its sale but simply requires that they be obtained by negotiation in the usual way and enforced according to the law of contract or in equity. ${ }^{111}$

The judges concluded: 'The matters which inform the adoption of a policy of the law as to the scope of the patent rights to sell and use a product, as they affect a patentee and owner of a chattel, point strongly to an acceptance of the exhaustion doctrine and away from the implied licence doctrine. ${ }^{112}$

It should be noted, though, that the United States-style patent exhaustion doctrine is still quite supportive of patentee's rights. The Supreme Court of the United States decision in Bowman $v$ Monsanto - a dispute involving transgenic soybean crop seeds - highlights the limits of the patent exhaustion doctrine in

\footnotetext{
${ }_{110}$ Calidad Pty Ltd $v$ Seiko Epson Corporation (n 104) [70].

${ }^{111}$ Ibid [76].

112 Ibid [84].
} 
protecting downstream users of patented products. ${ }^{113}$ In this matter, Kagan J wrote the lead judgment, ruling that harvesting and saving seed still constituted an unauthorised 'making' of the patented product. ${ }^{114}$

The judges were less keen to depend upon the implied licence doctrine, noting: 'Continued adherence to the implied licence doctrine is an unjustifiable gloss on the statutory language that confers monopoly rights on a patentee.' ${ }^{115}$ The judges warned: 'The decisions of the courts below show the danger of distraction from the language of the statute that is encouraged by that doctrine.' ${ }^{116}$ The judges chided the judges in the lower courts: 'In this case the implied licence doctrine was utilised as a juridical peg on which to hang not the patentee's permission to use the patented product, but rather unexpressed restrictions on the purchaser's rights in that regard to which the purchaser had not consented. ${ }^{\prime 17}$ The High Court of Australia would not approve of the position of some American historians, like Sean O'Connor, who maintain that patent exhaustion is actually derived from the doctrine of the implied license. ${ }^{118}$

113 Bowman v Monsanto Co. et al. 133 S. Ct 420 (2013). For commentary on this litigation, see: Charles Lawson, 'Juridifying the Self-Replicating to Commodify the Biological Nature Future: Patents, Contracts and Seeds' (2011) 20 (4) Griffith Law Review 851; Berris Charnley, 'Cui Bono? Gauging the Successes of Publicly-Funded Plant Breeding' in Charles Lawson and Berris Charnley (ed.), Intellectual Property and Genetically Modified Organisms: A Convergence in Laws, (Routledge 2015), 7; Christopher Spennemann, 'Patent Exhaustion and Seeds: Implications of the US Supreme Court Opinion in Bowman v Monsanto (2013)' in Robert D. Anderson, Pires de Carvalho, and Antony Taubman (ed.), Competition Policy and Intellectual Property in Today's Global Economy, (CUP 2021), 371.

114 Bowman v Monsanto Co. et al. (n 113).

115 Calidad Pty Ltd v Seiko Epson Corporation [2020] (n 104) [110].

116 Ibid.

117 Ibid.

118 Sean O'Connor, 'The Damaging Myth of Patent Exhaustion' (2020) 28 (3) Texas Intellectual Property Law Journal 443; Sean O'Connor, 'Origins of Patent Exhaustion: Jacksonian Politics, 'Patent Farming,' and the Basis of the Bargain', University of Washington School of Law Research Paper No. 2017-05, 2017, available at https://papers.ssrn.com/sol3/papers.cfm?abstract_id=2920738 (accessed 1 August 2021). 
The High Court of Australia has also been hostile to a broad reading of implied licences in copyright matters. ${ }^{119}$

The decision of the majority of the High Court of Australia is to be welcomed - especially given its focus on the larger economic and social objectives to be achieved by the patent exhaustion doctrine. The ruling also provides a helpful critique of the approach of the Federal Court of Australia and the Full Court of the Federal Court of Australia - which perhaps unduly privileged the interests of the patent holders. The decision follows other patent matters - such as the Myriad dispute over gene patents - in which the High Court of Australia has taken a much more circumspect view of patent rights than the Federal Court of Australia. ${ }^{120}$

\subsubsection{The Additional Judgment of Gageler J}

While agreeing with the majority judgment, Gageler J made some additional comments about the virtue of the patent exhaustion doctrine:

The exhaustion of rights doctrine has a lineage that is decades longer than the lineage of the implied licence doctrine. It has been shown by repeated application in the United States to be workable and coherent. It sets clear statutory boundaries. It respects longstanding common law principle. It does not need to enlist equity in some way to prop it up. It strikes an appropriate balance between the interests of patentees and the owners of patented

119 Copyright Agency Limited v State of New South Wales (2008) HCA 35 ('The Surveyors Case'); for commentary, see Judith Bannister, 'Public Access to Copyright Works Submitted to Government: Copyright Agency Ltd v New South Wales and the Implications for Information Access' (2008) 36(3) Federal Law Review 381.

${ }^{120}$ D'Arcy v Myriad Genetics Inc [2015] HCA 35. For commentary, see Matthew Rimmer, 'An Exorbitant Monopoly: The High Court of Australia, Myriad Genetics, and Gene Patents', in Duncan Matthews and Herbert Zech (ed.), Research Handbook on Intellectual Property and the Life Sciences (Edward Elgar 2017), 56. 
products. In so doing, it fits comfortably with the statutory object of the Patents Act 1990 as well as with the statutory language. ${ }^{121}$

The judge observed: 'Exhaustion of the right of the patentee to prevent others from using and selling patented goods upon exercise of the patentee's right to sell will have the consequence that a patentee who seeks to restrict downstream use or resale or other disposal of patented goods will be confined to seeking to impose those restrictions by contract or other enforceable arrangement.' ${ }^{122}$

This reasoning raises public policy questions about the interaction between intellectual property and contract law. It would be problematic if patent holders were still able to impose restrictions on, for instance, repair by contract or enforceable arrangement. There may well need to be further law reform to deal with this particular issue.

\subsubsection{The Minority Judgment of Nettle, Gordon, and Edelman JJ}

The minority judgment of Nettle, Gordon, and Edelman JJ would have allowed the appeal in part. ${ }^{123}$

The minority judgment declined to adopt the patent exhaustion theory:

To now adopt the exhaustion theory diminishes the rights granted under the Australian Patents Act 1990. Under the exhaustion theory, a patentee cannot seek to control or limit, as a matter of patent law, what can be done by a purchaser of a patented product on notice of a condition of restraint; the patentee is left with only whatever rights and remedies are available in

\footnotetext{
${ }^{121}$ Calidad Pty Ltd $v$ Seiko Epson Corporation [2020] (n 104) [134].

122 Ibid [135].

${ }^{123}$ Ibid.
} 
contract, and no rights and remedies under patent law. For our part, there is no principled reason for such a change. ${ }^{124}$

The minority judges were of the view that the patent exhaustion theory had its origins in United States patent law, and did not have a clear foundation in Australian patent law. The minority judges insisted: 'It is for Parliament, not the courts, to make such a fundamental change to patent rights.' ${ }^{125}$

The minority judges considered the precedents in respect of patent law and repair. The judges observed:

The central issue is whether an alleged infringer has 'made' a patented article as defined by the integers of the claim. In each case, that is a question of fact and degree to be decided according to the nature of the article as so defined . In making that decision, it assists to ask whether what the alleged infringer has done is to repair the article as opposed to making a new article. It needs also to be borne in mind that 'repair' may entail considerable disassembly, the removal and replacement of significant constituent parts, and reassembly on a mass production basis, without amounting to 'making' a new article. ${ }^{126}$

Focusing upon patent infringement and 'making', the judges held that 'the work performed on Category 1, 2, 3 and 4 and Category A cartridges - as later described - did not amount to making the patented invention but the work performed on Category 5, 6 and 7 and Category B cartridges did.' 127

The minority judgment is somewhat more quietist in its approach to the topic of patent law - showing a reluctance to recognise the patent exhaustion doctrine without guidance from Parliament. Nonetheless, the judges are very

\footnotetext{
124 Ibid [146].

125 Ibid [203].

126 Ibid [263].

127 Ibid [143].
} 
much concerned with the treatment of repairs in patent infringement proceedings.

\subsubsection{Context}

The ruling builds upon a previous precedent in some respects. The High Court of Australia - albeit with a differently constituted bench - has expressed concern about the impact of intellectual property upon competition in the marketplace in a copyright case involving mod-chipping the Sony PlayStation. ${ }^{128}$ In that matter, Kirby J noted: 'The right of the individual to enjoy lawfully acquired private property (a CD ROM game or a PlayStation console purchased in another region of the world or possibly to make a backup copy of the CD ROM) would ordinarily be a right inherent in Australian law upon the acquisition of such a chattel. ${ }^{129}$ The High Court of Australia was concerned in this case that the over-protection of intellectual property rights (through copyright law and technological protections) would have negative outcomes in terms of consumer rights and competition policy. The new decision in the patent matter over printer cartridges builds upon the earlier precedent in important ways in its promotion of consumer rights, competition policy, and sustainable development. The High Court of Australia has certainly been showing an interest in the larger public policy purposes of intellectual property in recent matters before the court. ${ }^{130}$

128 Stevens v Kabushiki Kaisha Sony Computer Entertainment [2005] HCA 58.

${ }^{129}$ Ibid [216].

${ }^{130}$ The High Court of Australia discussed the public policy purposes of intellectual property at length in the dispute over plain packaging of tobacco products in JT International SA $v$ Commonwealth of Australia [2012] HCA 43; for commentary, see Matthew Rimmer, 'The High Court of Australia and the Marlboro Man: The Battle Over The Plain Packaging of Tobacco Products', in Tania Voon, Andrew Mitchell, and Jonathan Liberman (Ed.) Regulating Tobacco, Alcohol and Unhealthy Foods: The Legal Issues (Routledge 2014), 337. 
The Law Council of Australia has argued that the recent High Court of Australia decision on patent exhaustion may be applied in the future in respect of other fields of intellectual property. ${ }^{131}$ The Law Council of Australia observed: 'The Calidad decision makes it clear that patentees' rights are subject to exhaustion on sale in Australia and brings Australian jurisprudence in line with that of trading partners such as the United States (US) and the European Union.' ${ }^{132}$ The Law Council of Australia suggests that the reasoning in the decision may be applied in relation to other IP rights including, particularly, copyright.' ${ }^{133}$ There could be scope for future harmonisation by the courts on the exhaustion of intellectual property rights. In its final report, the Productivity Commission also considers whether the exhaustion doctrine could be expanded to other fields of intellectual property - such as copyright law. ${ }^{134}$ In the end, the Productivity Commission declines to recommend that the legislature codify the exhaustion doctrine across other intellectual property regimes. ${ }^{135}$ Nonetheless, the Productivity Commission recognises that 'it is still open to Australian courts to find that the exhaustion doctrine applies in relation to copyright materials. ${ }^{\prime 36}$

In the meantime, Davies Collison Cave observed that there remained many uncertainties: 'The metes and bounds of the Doctrine of Exhaustion as concerning repair (and in general) are at present unknown, and can take shape

${ }^{131}$ Law Council of Australia, 'Submission to the Productivity Commission - Right to Repair Issues Paper (December 2020)', Submission 114 to the Issues Paper, Productivity Commission, 12 February 2021, 12, available at https://www.pc.gov.au/ data/assets/pdf file/0007/272896/sub114-repair.pdf (accessed 1 August 2021).

132 Ibid.

133 Ibid.

134 Productivity Commission, 'Right to Repair: Inquiry Report No. 97' (n 20).

135 Ibid 186.

${ }^{136}$ Ibid 186. 
only once there has been judicial application of the doctrine over a range of circumstances.' $^{137}$

\section{Reform of Australian Patent Law Defences and Exceptions}

In its investigation of Australia's intellectual property arrangements, the Productivity Commission highlighted the need for patent law reform:

While the patent system has a role to play in promoting socially valuable and additional innovations - especially in highly codified technologies that involve large sunk costs such as machinery and pharmaceuticals - it is clear that the system is poorly targeted and in many cases provides excessively strong patent rights.

In an environment where the patent system is not effectively targeting innovations that provide net benefits to the community, overly-strong patent rights compound the costs associated with false positives. Longer rights increase the scope for unused patents to be opportunistically revived to capture infringing firms, which imposes costs without a resulting increase in innovation.

As a large net importer of patented technology, overcompensation in the strength of rights is particularly costly for Australia. And as a relatively small consumer market for technology, stronger rights in Australia do little to promote innovation by global firms. ${ }^{138}$

${ }^{137}$ Davies Collison Cave, 'Inquiry of the Productivity Commission: Right to Repair', Submission 141 to the Issues Paper, Productivity Commission, 19 March 2021, 5, available at https://www.pc.gov.au/ data/assets/pdf file/0011/273998/sub141-repair.pdf (accessed 1 August 2021).

138 Productivity Commission, 'Intellectual Property Arrangements - Final Report' (Productivity Commission, 2016), 214, available at https://www.pc.gov.au/inquiries/completed/intellectualproperty/report (accessed 1 August 2021). 
The Productivity Commission focused in particular upon patent objectives, patent thresholds, and patent flexibilities, such as compulsory licensing and crown use. However, in spite of its concern with overprotection under patent law, there was not a clear discussion of the right to repair. There was a mention in passing of the spare parts defence in relation to designs law.

After much public policy activity, the Productivity Commission was given a new reference by the Australian Government to investigate the right to repair in late October 2020. ${ }^{139}$ In its 2021 draft report, the Productivity Commission found that the 'Calidad' case helped clarify issues around repair of patented products. ${ }^{140}$ The Productivity Commission observed: 'As a result [of the High Court decision], consumers can do what they like with patented products that have been purchased from the patentee, so long as a new product is not made in such a way as to infringe the patentee's exclusive manufacturing rights.' ${ }^{141}$ The Productivity Commission acknowledged: 'Some uncertainty remains as to where exactly the boundary lies, particularly in different factual circumstances (such as the dismantling for repair of a simple (non-complex) product.' ${ }^{142}$ The Productivity Commission hoped that judicial consideration would resolve any uncertainty or ambiguity in the decision: 'Future cases on the issue will serve to further clarify the Calidad decision.' ${ }^{143}$ In its draft report, the Productivity Commission, though, seemed reluctant and hesitate to make any specific recommendations in respect of patent law and the right to repair.

\footnotetext{
139 Productivity Commission, 'Right to Repair' (Productivity Commission, 2020) https://www.pc.gov.au/inquiries/current/repair (accessed 1 August 2021).

${ }_{140}$ Productivity Commission, 'Right to Repair: Draft Report' (n 20).

${ }^{141}$ Ibid 174.

142 Ibid 174.

${ }^{143}$ Ibid 174.
} 
In its final report, the Productivity Commission also makes reference to the Calidad case. ${ }^{144}$ The Productivity Commission reiterated that 'future cases will serve to test the High Court's reasoning and clarify the scope of the doctrine, particularly as it applies to different acts of repair.' ${ }^{145}$ The Productivity Commission recounted evidence that repairs could nonetheless still raise issues around patent infringement: 'If a repairer was to undertake significant repairs to a product (including where repairs involve replacing a large number of parts, or multiple substantial parts) they could risk infringing a manufacturer's exclusive patent rights as to the manufacture (making) of their inventions. ${ }^{146}$ Nonetheless, the Productivity Commission was unconvinced that there was sufficient evidence to establish that patent laws were a clear impediment to repairs. In a footnote, the Productivity Commission observed that there could be scope to revisit the issue in the future: 'While it could not be established that other forms of IP, including patents, designs and trademarks, are materially impacting product repairs to warrant reform at this time, this is not to say that issues in these areas do not exist, nor that they may not become a material issue requiring government intervention in the future.' ${ }^{147}$

In this paper, it is argued that more could be done in terms of patent law reform, above and beyond the High Court of Australia ruling in the Calidad matter. This paper contends that there is scope to build upon the Productivity Commission's initial policy recommendations, and put forward reforms, which would help embed the right to repair in Australian patent law. In particular, there could be the establishment of a new defence or exception in respect of the right to repair under patent law. There could be the constructive use of compulsory

\footnotetext{
${ }^{144}$ Productivity Commission, 'Right to Repair: Inquiry Report No. 97' (n 20), 179.

145 Ibid 178.

146 Ibid 178.

147 Ibid 180.
} 
licensing, crown use, and competition law to ensure that monopolies do not form in the aftermarkets. There could also be reform of contract law to ensure that the right to repair cannot be contracted out of. Such reforms would build upon the positive outcome of the High Court of Australia decision in respect of the Calidad case.

\subsection{A Defence for the Right to Repair}

This paper submits that there is a need for an equivalent defence for the right to repair across the various fields of intellectual property. This is particularly important given that many technologies subject to repair involve a combination of intellectual property. In Australian law, there is a spare parts defence under designs law - but other regimes do not have such a clearcut defence.

Australian copyright law does not currently recognise a clear right to repair. In its draft report, report, the Productivity Commission recommended that there should be a defence for repair under copyright law - whether it was a general defence of fair use or a specific fair defence of fair dealing for repair. ${ }^{148}$ The Productivity Commission also recommended amending copyright laws to ensure that independent repairers were not subject to legal action for circumventing technological protection measures. ${ }^{149}$ There have been similar concerns about the overbroad protection afforded to technological protection

\footnotetext{
${ }_{148}$ Productivity Commission, 'Right to Repair: Draft Report' (n 20).

149 Ibid.
} 
measures interfering with the right to repair in the United States, ${ }^{150}$ and Canada. ${ }^{151}$

In its final report, the Productivity Commission made some specific findings and recommendations in respect of copyright law. ${ }^{152}$ Finding 5.1 was that 'copyright laws that prevent third-party repairers from accessing repair information (such as repair manuals and diagnostic data) are the most significant unnecessary intellectual property-related barrier to repair in Australia.' ${ }^{153}$ Recommendation 5.1 was that 'the Australian Government should amend the technological protection measures (TPM)) regime in the Copyright Act 1968 (Cth) and Copyright Regulations 2017 to better facilitate repairers' access to embedded information protected by TPMs necessary for issue diagnosis and repair. ${ }^{\prime 54}$ Recommendation 5.2 was that 'the Australian Government should amend the Copyright Act 1968 (Cth) to include an exception that allows for the reproduction and sharing of repair information.' ${ }^{155}$ In the short term, the Productivity Commission called for the recognition of a fair dealing for the purposes of repair. The Productivity Commission observed: 'In the medium to long term, the Australian Government should pursue a more flexible copyright exception regime, including a principles-based "fair use" exception. ${ }^{156}$ Recommendation

\footnotetext{
150 Perzanowski and Schultz (n 10); Bryan Bello and Patricia Aufderheide, ‘The DMCA, Database Protection, and Right to Repair: The Long Tail of Public Interest Activism in the First Digital Copyright Decade' (2021) 56 (1) Information \& Culture, available at https://papers.ssrn.com/sol3/papers.cfm?abstract id $=3740187$ (accessed 1 August 2021); MC Forelle, 'Copyright and the Modern Car: Colliding Visions of the Public Good in DMCA Section 1201 Anti-Circumvention Proceedings' (2021) New Media \& Society 1.

151 Bill C-272, An Act to Amend the Copyright Act (Diagnosis, Maintenance or Repair) (Canada). For commentary, see Anthony Rosborough, 'Unscrewing the Future: The Right to Repair and the Circumvention of Software TPMs in the EU' (2020) 11 Journal of Intellectual Property, Information Technology \& E-Commerce Law 26.

152 Productivity Commission, 'Right to Repair: Inquiry Report No. 97' (n 20).

153 Ibid 180.

${ }^{154}$ Ibid 184.

155 Ibid 193.

156 Ibid 193.
} 
5.3 was to prohibit the contracting out of copyright exceptions, including those relating to repair. ${ }^{157}$

Section 72 of the Designs Act 2003 (Cth) lays down some elaborate, convoluted rules in respect of certain repairs not infringing registered designs. The nature and scope of this defence was recently explored by the Federal Court of Australia in the 2019 case of GM Global Technology Operations LLC v S.S.S. Auto Parts Pty Ltd. ${ }^{158}$ It would appear from the outcome of the case that the spare parts exemption - the right of repair defence - has a substantive impact in providing protection for repairs from the threat of action for designs infringement. There has been some scholarly discussion about the operation of the defence of right to repair in respect of the Australian designs law regime. ${ }^{159}$ It is submitted that the spare parts defence should be modernised, so that there is a general defence for repair under designs law. The Productivity Commission, though, declined to reform the spare parts defence in designs law. ${ }^{160}$ The Productivity Commission noted that, 'with further cases, the courts will be able to fully explore the scope and reach of the defence.' ${ }^{161}$

Instead of relying upon the status quo, as recommended by the Productivity Commission, a defence for the right to repair could be crafted in respect of Australian patent law. There has been recent experience in codifying patent exceptions - with the introduction of a defence of experimental use in

\footnotetext{
157 Ibid 196.

158 Section 72 of the Designs Act 2003 (Cth); GM Global Technology Operations LLC v S.S.S. Auto Parts Pty Ltd (n 12).

159 Mitchell Adams, 'The "Third Industrial Revolution": 3D Printing Technology and Australian Designs Law' (2016) 24(1) Journal of Law, Information and Science 1; and Tyrone Berger, '"Substantial Similarity' under Australian Design Law: Application to 3D Printing' in Dinusha Mendis, Mark Lemley, and Matthew Rimmer (ed.), 3D Printing and Beyond: Intellectual Property and Regulation (Edward Elgar Publishing 2019), 294.

${ }^{160}$ Productivity Commission, 'Right to Repair: Inquiry Report No. 97' (n 20) 167.

${ }^{161}$ Ibid 167.
} 
Australian patent law. ${ }^{162}$ A similar approach could be taken to the topic of the right to repair. Ideally, a general defence for the right to repair would be crafted - with a range of factors to be taken into account by the courts. Indicative factors could include the purpose and character of the use; the nature of the patented invention; the amount or the portion used in relation to the patented invention as a whole; and the impact of the use on the market of the for or value of the patented invention.

Such a defence would help rebalance the patent regime - and ensure that consumers, independent repairers, and small to medium businesses could repair patented inventions, without fear of litigation. As Lucas Osborn has noted, 'Across the IP spectrum, individual access and empowerment in the areas of design and manufacturing create tensions for laws constructed on assumptions about the legal sophistication and monetary resources of the regulated'. ${ }^{163}$

\subsection{Compulsory Licensing}

For a long while, Australia's compulsory licensing provisions were anachronistic, formed to protect domestic industries in an era industrial manufacturing. As Professor Charles Lawson observed in 2008, 'the provisions need to be revisited by Parliament and recast in meaningful and purposeful text. ${ }^{164}$

${ }^{162}$ Matthew Rimmer, 'The Freedom to Tinker: Patent Law and Experimental Use' (2005) 15 (2) Expert Opinion on Therapeutic Patents 167; Intellectual Property Laws Amendment (Raising the Bar) Act 2012 (Cth); Senator Kim Carr, 'Second Reading Speech on the Intellectual Property Laws (Raising the Bar) Bill 2011 (Cth)', Hansard, Australian Senate, Australian Parliament, 22 June $2011,3485$.

${ }^{163}$ Lucas Osborn, 3D Printing and Intellectual Property (CUP 2019), 229.

${ }^{164}$ Charles Lawson, 'Public Interest Compulsory Licensing under the Patents Act 1990 (Cth): A Real Incentive or a Barrier to Working?' (2008) 19 Australian Intellectual Property Journal 129, 147. 
In its inquiry into intellectual property arrangements, the Productivity Commission also recommended that there was a need to modernise and reform Australia's compulsory licensing powers under the patent act. ${ }^{165}$

The Intellectual Property Laws Amendment (Productivity Commission Response Part 2 and Other Measures) Act 2020 (Cth) provides for reforms in respect of compulsory licensing. The Minister for Industry, Science, and Technology, Karen Andrews, explained the intent of the reforms:

Schedule 4 improves the clarity and certainty for compulsory licensing of patents. It requires the courts to consider whether it is in the public interest to grant a compulsory licence. There was concern that the previous test had the potential to protect the interests of a particular industry, at a net cost to the broader community. The new test will ensure that compulsory licences are only granted when there will be an overall net benefit to the Australian community. Schedule 4 will also clarify the process for compulsory licensing of inventions that build and improve on a previous patent. ${ }^{166}$

Schedule 4 implements recommendations made in the 2013 Productivity Commission Report regarding compulsory licensing. The Act changes the test applied by the courts when determining whether a compulsory license should be granted. The amendments remove the current 'reasonable requirement of the public' test and replace it with a 'public interest' test. These amendments improve the balance between the rights of the patent owner and the interests of the broader public.

\footnotetext{
165 Productivity Commission, 'Intellectual Property Arrangements - Final Report' (n 138).

166 Hon. Karen Andrews, 'Second Reading Speech on the Intellectual Property Laws Amendment (Productivity Commission Response Part 2 and Other Measures) Bill 2019 (Cth)', Hansard, House of Representatives, Parliament of Australia, 5 February 2020, 297.
} 
Compulsory licensing could conceivably be deployed in Australia - where patent holders refused to allow for independent repairs in respect of patented inventions. There has been previously discussion about the use of compulsory licensing in the context of public health - particularly in respect of gene patents, ${ }^{167}$ and access to essential medicines. ${ }^{168}$ The topic of compulsory licensing has also emerged in the context of the coronavirus pandemic. ${ }^{169}$

Compulsory licensing could be a useful mechanism to address repair market failures.

\subsection{Crown Use or Government Use}

In its investigation of Australia's intellectual property arrangements, the Productivity Commission recommended that there was a need to reform Australia's crown use powers under the patent regime. ${ }^{170}$

The Intellectual Property Laws Amendment (Productivity Commission Response Part 2 and Other Measures) Act 2020 (Cth) also provided for the reform of the Crown use provisions in respect of both patent law and designs law. Minister for Industry, Science, and Technology, Karen Andrews, discussed the regime:

Schedule 2 also protects the rights of patent holders, by improving accountability for Crown use as well as providing more guidance for determining the remuneration to be paid to the patent owner. Government

\footnotetext{
167 Australian Law Reform Commission, Genes and Ingenuity: Gene Patenting and Human Health, Sydney: Australian Law Reform Commission, 2004, https://www.alrc.gov.au/publication/genesand-ingenuity-gene-patenting-and-human-health-alrc-report-99/ (accessed 1 August 2021).

168 Joint Standing Committee on Treaties, 'Chapter 9 Protocol amending the TRIPS Agreement (Geneva, 6 December 2005)' (Australian Parliament, 2007), available at https://www.aph.gov.au/parliamentary_business/committees/house_of_representatives_committees?ur $1=/$ jsct/9may2007/report/chapter9.htm (accessed 1 August 2021).

169 MSF, 'Compulsory Licenses, the TRIPS Waiver, and Access to COVID-19 Medical Technologies', MSF Briefing Document, May 2021, available at https://msfaccess.org/compulsorylicenses-trips-waiver-and-access-covid-19-medical-technologies (accessed 1 August 2021).

170 Productivity Commission, 'Intellectual Property Arrangements - Final Report' (n 138).
} 
agencies will be required to seek to negotiate with the patent owner and to obtain the authorisation of the relevant minister before invoking Crown use. At the Commonwealth level, the relevant minister is the minister responsible for administering the Patents Act, and at the state and territory level, it is the Attorney-General. This will ensure that Crown use is only used in appropriate circumstances. ${ }^{171}$

The explanatory memorandum noted that 'Crown use is a rarely used safeguard', which 'allows the government to step in when action is necessary to deal with an emergency, or other public interest issues, and access patented inventions and designs.' ${ }^{172}$ The explanatory memorandum notes: 'This Act introduces measures to improve transparency and accountability of Crown use' ${ }^{173}$ Under the new regime, 'The amendments modify the Acts to clarify the circumstances in which Crown use can be invoked, introduce a process of Ministerial oversight, and provide better guidance to the courts on the remuneration standard that should be used in determining the level of compensation to be paid to the rights holder. $^{\prime 174}$

Crown use or government use could be used in Australia to provide access to patented inventions if there were issues about patent thickets in the marketplace. There has often been issues in terms of gaining access to patented inventions, where there is a thicket of patents. ${ }^{175}$ Professor Michael Heller and

171 Andrews (n 166) 297.

172 Explanatory Memorandum for the Intellectual Property Laws Amendment (Productivity Commission Response Part 2 and Other Measures) Bill 2019 (Cth), https://parlinfo.aph.gov.au/parlInfo/search/display/display.w3p;query=Id\%3A\%22legislation $\% 2$ Fems \%2Fs1216 ems f72c231a-ab5a-4563-8aaa-f78983def254\%22 (accessed 1 August 2021).

173 Ibid.

174 Ibid.

175 Stefan Wagner, 'Are Patent Thickets Smothering Innovation?' (Yale Insights, 22 April 2015), available at https://insights.som.yale.edu/insights/are-patent-thickets-smothering-innovation (accessed 1 August 2021). 
Professor Rebecca Eisenberg have discussed the problem of the tragedy of the anti-commons. ${ }^{176}$ Emerging fields of technology - such as 3D printing, robotics, and nanotechnology - have seen the rapid appearance of patent thickets. ${ }^{177}$

Likewise, Crown use or government use could be deployed in Australia if there were problems about gaining access to patented inventions because of patent troll behaviour. Patent trolls are non-practising entities, which threaten patent litigation, unless they receive a substantial patent licence fee. ${ }^{178}$ Professor Mark Lemley and his colleagues have suggested that bad actors like patent trolls are symptomatic of larger problems with the patent system. ${ }^{179}$

During the coronavirus public health crisis, Shadow Minister the Hon. Brendan O'Connor suggested that the Australian Government should make use of the Crown Use provisions: 'I also think the government will need to detail how Crown use of patents may be invoked, particularly for use for repurposed manufacturing businesses, to address shortages of essential goods impacted by disrupted supply chains.' ${ }^{180}$ He commented: 'I have written to the Minister for Industry, Science and Technology inquiring as to whether the government had explored using this provision, particularly for urgent manufacturing of suppliers, such as facial masks or goods in short supply due to disrupted supply chains. ${ }^{181}$

\footnotetext{
${ }^{176}$ Michael Heller and Rebecca Eisenberg, 'Can Patents Deter Innovation? The Anticommons in Biomedical Research' (1998) 280 (5364) Science 697.

177 World Intellectual Property Organization, ‘World Intellectual Property Report 2015 Breakthrough Innovation and Economic Growth' (World Intellectual Property Organization, 2015), https://www.wipo.int/publications/en/details.jsp?id=3995 (accessed 1 August 2021).

178 James Bessen and Michael Meurer, 'The Direct Costs from NPE Disputes' (2014) 99 Cornell Law Review 387.

179 Mark Lemley and A. Douglas Melamed, 'Missing the Forest for the Trolls' (2013) 113 Columbia Law Review 2117; Mark Lemley and Samantha Zyontz, 'Does Alice Target Patent Trolls?' (2021) Journal of Empirical Legal Studies, available at https://papers.ssrn.com/sol3/papers.cfm?abstract id=3561252 (accessed 1 August 2021).

180 The Hon. Brendan O'Connor, 'Second Reading Speech on the Coronavirus Economic Response Package Omnibus Bill 2020 (Cth)', Hansard, House of Representatives, Parliament of Australia, 23 March 2020, 2801.

${ }^{181}$ Ibid.
} 
The Australian Government, though, has not invoked the Crown Use provisions during the public health emergency.

\subsection{Competition Oversight}

The Harper Review and the Productivity Commission recommended the repeal of s 51 (3) of the Competition and Consumer Act 2010 (Cth) - because of the view that it was unduly confining the ability of the Australian Competition and Commission to provide oversight of the competition impacts of intellectual property. $^{182}$

The repeal of s 51 (3) of the Competition and Consumer Act 2010 (Cth) in 2019 will mean that the ACCC will have greater oversight in respect of the intersection between intellectual property and competition policy. The ACCC has previously conducted inquiries into various after-markets. The regulator has investigated motor vehicles and spare parts, ${ }^{183}$ as well as agricultural machinery. ${ }^{184}$ Arguably, the ACCC needs to play a more active role in policing competition in aftermarkets in Australia - subject to intellectual property rights. The ACCC has

182 Ian Harper, Peter Anderson, Sue McCluskey and Michael O'Bryan, Competition Policy Review: Final Report (The Australian Government, March 2015), available at http://competitionpolicyreview.gov.au/files/2015/03/Competition-policy-review-report_online.pdf (accessed 1 August 2021); Productivity Commission, 'Intellectual Property Arrangements Final Report' (n 138).

183 Australian Competition and Consumer Commission, 'New Car Retailing Industry Market Study' (Australian Competition and Consumer Commission, 2017), available at https://www.accc.gov.au/focus-areas/market-studies/new-car-retailing-industry-market-study (accessed 1 August 2021). See also Australian Competition and Consumer Commission, 'Motor Vehicle Sales and Repairs - An Industry Guide to the Australian Consumer Law' (Australian Competition and Consumer Commission, 2018), available at https://www.accc.gov.au/publications/motor-vehicle-sales-repairs-an-industry-guide-to-the-australianconsumer-law (accessed 1 August 2021).

184 Australian Competition and Consumer Commission, 'Agricultural Machinery Market Study' (n 4). 
become increasingly active in regulating the digital economy - so there is hope that such a priority will lead to a focus on the right to repair. ${ }^{185}$

In its inquiry into the right to repair, the Productivity Commission considered the specific question of competition in repair markets. ${ }^{186}$ In its findings, the Productivity Commission recognised that some limits on access to repair supplies lacked sound justification. ${ }^{187}$ However, the Productivity Commission was of view that there was no evidence of a systematic competition problem across all repair markets. ${ }^{188}$ In its findings, the Productivity Commission held that limits on repair supplies for agricultural machinery are causing harm. ${ }^{189}$ However, the Productivity Commission thought that the extent of harm in mobile phone and tablet repair markets is uncertain. ${ }^{190}$ The Productivity Commission maintained that repair of medical devices and equipment required further investigation. ${ }^{191}$ The Productivity Commission reiterated that ACCC action could address concerns about enforcement. ${ }^{192}$ In particular, the Productivity Commission recommended that the ACCC should investigate conduct in watch repair markets. ${ }^{193}$

In the United States, there have been concerns about the laissez-faire approach taken to competition regulation by the Department of Justice and the Federal Trade Commission, particularly under the Trump Administration. ${ }^{194}$

\footnotetext{
${ }^{185}$ Ben Butler, “The Most Hated Regulator in Australia”: Rod Sims Warns Business He's Still Watching' (The Guardian, 4 October 2020) https://www.theguardian.com/australianews/2020/oct/04/the-most-hated-regulator-in-australia-rod-sims-warns-business-hes-still-watching (accessed 1 August 2021).

186 Productivity Commission, 'Right to Repair: Inquiry Report No. 97' (n 20) 111-160.

187 Ibid 133.

188 Ibid 133

189 Ibid 138.

${ }^{190}$ Ibid 142.

191 Ibid 146

192 Ibid 152.

193 Ibid 152.

194 David Dayen, Monopolized: Life in the Age of Corporate Power (The New Press 2020), 282-283.
} 
There has been alarm that monopoly power in key markets has been uncontrolled and unrestrained. ${ }^{195}$ As Zephyr Teachout has argued, there is a need for a stronger enforcement of competition law and policy to break up monopolies including in respect of after-markets. ${ }^{196}$ President Joe Biden has issued executive orders relating to the right to repair in order to boost fair competition in the United States. ${ }^{197}$ His new appointee Lina Khan and the Federal Trade Commission have issued policy advice, emphasizing that the agency would prioritize enforcement action against repair restrictions. ${ }^{198}$

Arguably, the ACCC should show a similar enthusiasm for enforcement action in relation to repair restrictions, as its American counterpart. The new Albanese Government has been enthusiastic about competition law reform. Assistant Minister for Competition, the Hon. Andrew Leigh MP, has given an address about the new Government's legislative priorities. ${ }^{199}$ He stressed: 'The

195 Michelle Meagher, 'Monopoly Power is Running Wild. We Need Tough Competition Laws To Rein It In' (The Guardian, 28 September 2020), available at https://www.theguardian.com/commentisfree/2020/sep/28/monopoly-power-competition-policylawyer-city (accessed 1 August 2021).

196 Zephyr Teachout, Break 'Em Up: Recovering Our Freedom From Big Ag, Big Tech, and Big Money (Macmillan Publishers 2020).

197 The White House, 'Fact Sheet: Executive Order on Promoting Competition in the American Economy', Press Release, 9 July 2021, available at https://www.whitehouse.gov/briefingroom/statements-releases/2021/07/09/fact-sheet-executive-order-on-promoting-competition-in-theamerican-economy/ (accessed 1 August 2021).

198 Federal Trade Commission, 'FTC to Ramp Up Law Enforcement Against Illegal Repair Restrictions', Press Release, 21 July 2021, available at https://www.ftc.gov/news-events/pressreleases/2021/07/ftc-ramp-law-enforcement-against-illegal-repair-restrictions (accessed 1 August 2021); Federal Trade Commission, 'Policy Statement of the Federal Trade Commission on Repair Restrictions Imposed by Manufacturers and Sellers' (21 July 2021), available at https://www.ftc.gov/system/files/documents/public statements/1592330/p194400repairrestrictionspoli cystatement.pdf (accessed 1 August 2021); Lina Khan, 'Remarks of Chair Lina M. Khan Regarding the Proposed Policy Statement on Right to Repair' (Federal Trade Commission, 21 July 2021), available at https://www.ftc.gov/public-statements/2021/07/remarks-chair-lina-m-khanregarding-proposed-policy-statement-right-repair (accessed 1 August 2021); Makena Kelly, 'FTC Pledges to Fight Unlawful Right to Repair Restrictions' (The Verge, 21 July 2021), available at https://www.theverge.com/2021/7/21/22587331/right-to-repair-apple-iphone-ftc-lina-khan-openmeeting (accessed 1 August 2021).

199 Hon. Andrew Leigh, 'Address to the Australian Government Solicitor Civil Regulation Conference, Sydney' (Treasury Portfolio, Australian Government, 2 November 2022), available at 
Albanese Government believes good competition is the bedrock of our economy.' 200 Leigh warned: 'We also know the danger that unchecked monopolists pose to our economy and our democracy. ${ }^{201}$ He commented: 'Competition prevents monopolists exploiting their "kingly prerogative" and harming democracy.' ${ }^{202}$ Leigh cited the work of senior US officials, Lina Khan and Tim Wu in his speech, concluding: 'Competition policy should be one of the factors that we consider when implementing regulation, given regulatory costs for new businesses are larger relative to their size.' ${ }^{203}$ Leigh has promised competition law reform, and stronger enforcement action. ${ }^{204}$ In a further address, Leigh has vowed to take action in the field of the right to repair - especially in respect of competition law and policy, and consumer rights. ${ }^{205}$

There has been a larger push to better align the objectives of intellectual property and competition policy. ${ }^{206}$

\footnotetext{
https://ministers.treasury.gov.au/ministers/andrew-leigh-2022/speeches/address-australiangovernment-solicitor-civil-regulation (accessed 1 January 2023).

200 Ibid.

201 Ibid.

202 Ibid.

203 Ibid.

204 Sarah Martin, 'Labor vows to shake up “Cosy Monopolists” with Fines of Up to \$50m for AntiCompetitive Behaviour' (The Guardian, 9 July 2022), available at https://www.theguardian.com/australia-news/2022/jul/09/labor-vows-to-shake-up-cosy-monopolistswith-fines-of-up-to-50m-for-anti-competitive-behaviour (accessed 1 January 2023); Greg Jericho, 'Large Firms are Consolidating power like Scott Morrison Consolidates Jobs - and it's hurting Productivity' (The Guardian, 25 August 2022), available at https://www.theguardian.com/business/grogonomics/2022/aug/24/large-firms-are-consolidatingpower-like-scott-morrison-consolidates-jobs-and-its-hurting-productivity (accessed 1 January 2023); Harley Dennett, 'Revamp competition laws to boost growth with economic fairness: Andrew Leigh' (Mudgee Guardian, 13 November 2022), available at https://www.mudgeeguardian.com.au/story/7979678/dynamism-key-to-fairer-growth-leigh/?cs=12 (accessed 1 January 2023).

205 Leigh (n 8).

206 Robert D. Anderson, Pires de Carvalho, and Antony Taubman (ed.), Competition Policy and Intellectual Property in Today's Global Economy, (CUP 2021).
} 


\subsection{Contract Law and Consumer Rights}

In its inquiry into the right to repair, the Productivity Commission has been generally concerned with how contract law has impacted upon the ability of consumers and businesses to obtain repairs. ${ }^{207}$ There was in particular evidence from contract law expert Professor Leanne Wiseman on this topic in the Australian investigation. ${ }^{208}$

In its draft report and during the public hearings, the Productivity Commission also emphasized that the ACCC could take action under Australian Consumer Law in respect of consumer guarantees, contractual terms which were misleading or deceptive, unfair contractual terms, and unconscionable conduct. ${ }^{209}$ The Productivity Commission indicated that the regulator needed to take a robust approach in respect of contracting practices relating to repair, which were misleading and deceptive, unfair, or otherwise unconscionable.

There has been a longstanding concern about contracting out of repair. Back in 2009, the prescient Professor Estelle Derclaye identified tensions between intellectual property, contract law, and repair in her scholarship. ${ }^{210}$ She posed the question of whether it was lawful to block repair and recycling through end user license agreements in the European Union and the United States. In the context of Australia, there could also be reform of contract law to help reinforce such recognition of the right to repair under patent law. There should be protection to

\footnotetext{
207 Productivity Commission, 'Right to Repair: Draft Report' (n 20).

${ }^{208}$ Leanne Wiseman and Kanchana Kariyawasam, 'Re: Submission on the Right to Repair in response to the Productivity Commission's Issues Paper December 2020', Submission 105 to the Issues Paper of the Productivity Commission, 7 February 2021, https://www.pc.gov.au/ data/assets/pdf file/0005/272660/sub105-repair.pdf (accessed 1 August 2021).

209 Productivity Commission, 'Right to Repair: Draft Report' (n 20).

${ }^{210}$ Estelle Derclaye, 'Repair and Recycle Between IP Rights, End User License Agreements And Encryption' in Christopher Heath and Anselm Kamperman Sanders (ed.), Spares, Repairs and Intellectual Property Rights (Kluwer Law International 2009), 21-56.
} 
ensure that intellectual property owners cannot seek to contract out of, or undermine, the right to repair through the use of private contracts.

In its draft report, the Productivity Commission explores the use of enduser licence agreement term and conditions to impose limitations on the scope to repair. ${ }^{211}$ There was a recognition that there were various contractual barriers to repair: 'Some inquiry participants have argued that manufacturers use [End-User Licence Agreements] to limit the scope of repairs that third-party repairers may undertake by imposing restrictions on circumventing [technological protection measures], disassembly and other post-sale usage, repair and modification restrictions on consumers.' ${ }^{212}$ The Productivity Commission has sought further feedback on whether [End-User Licence Agreements] terms are unnecessarily discouraging third-party repairs. The Productivity Commission commented that there could be grounds for consumer law action if End-User Licence Agreements are misleading and deceptive in their nature.

The Productivity Commission has recommended: 'To reduce the risk of manufacturers using contractual arrangements (such as confidentiality agreements) to "override" the operation of any such reforms, it may be beneficial to amend the Copyright Act 1968 to prohibit the use of contract terms that restrict repair-related activities otherwise permitted under copyright law' ${ }^{213}$ This recommendation was embodied in the final report as well. ${ }^{214}$

The Productivity Commission should have gone further, and sought to prohibit the use of contract terms that restrict repair-related activities under other forms of intellectual property as well.

\footnotetext{
211 Productivity Commission, 'Right to Repair: Draft Report' (n 20).

212 Ibid 171.

213 Ibid 132.

${ }^{214}$ Productivity Commission, 'Right to Repair: Inquiry Report No. 97' (n 20) 35.
} 
In its final report, the Productivity Commission makes a number of recommendations in respect of repair rights under consumer law. ${ }^{215}$ In Finding 3.1, the Productivity Commission recommended that consumers sometimes lack the ability to exercise existing rights. ${ }^{216}$ Recommendation 3.1 calls for Australian consumer law to require software updates for a reasonable period. ${ }^{217}$ Recommendation 3.2 asked for the enablement of a super complaint process to enable consumer groups to lodge complaints on systemic issues associated with consumer guarantees. $^{218}$ Recommendation 3.3 sought an enhancement of alternative dispute resolution powers. ${ }^{219}$ Recommendation 3.4 recommended that the Australian Government enhance the regulator powers to enforce guarantees. The Productivity Commission also expressed concern that misleading manufacturer warranties can discourage independent repair. ${ }^{220}$

For its part, the ACCC has been boosting its enforcement action in the field of consumer rights. The ACCC has taken litigation in respect of misleading representations by FitBit in respect of refunds for faulty products. ${ }^{221}$

\section{Patent Law, the Right to Repair, and 3D Printing}

There has been concern about patent holders engaging in profiteering - not only in $2 \mathrm{D}$ printing, but also in $3 \mathrm{D}$ printing. ${ }^{222}$

\footnotetext{
215 Productivity Commission, 'Right to Repair: Inquiry Report No. 97' (n 20) 79-110.

216 Ibid 82.

217 Ibid 99.

218 Ibid 101.

${ }^{219}$ Ibid 107.

220 Ibid 123.

${ }^{221}$ Jessica Yun, 'ACCC takes Fitbit to Court for Allegedly Misleading Consumers about Refunds' (The Sydney Morning Herald, 24 October 2022), available at https://www.smh.com.au/business/consumer-affairs/accc-takes-fitbit-to-court-again-for-allegedlymisleading-consumers-about-refunds-20221024-p5bsdl.html (accessed 1 January 2023).

${ }^{222}$ Cory Doctorow, 'Ink-Stained Wretches: The Battle for the Soul of Digital Freedom Taking Place Inside Your Printer' (Electronic Frontier Foundation, 5 November 2020), available at
} 
While the litigation in Calidad is very much focused on 2D printing, it may nonetheless have ramifications for 3D printing and additive manufacturing, and emerging fields such as 4D printing. Furthermore, a proprietarian approach to patent law, as taken by the Federal Court of Australia and even the minority judges of the High Court of Australia, may also have an adverse impact upon communities - such as those in the Maker Movement - which support a culture of DIY repair, refurbishment of inventions, and open sharing. The majority position of the High Court of Australia in the Calidad litigation on patent exhaustion may be much more conducive to support a culture of repair and remaking in secondary markets.

The Maker Movement has advocated the open development, collaboration, and sharing of inventions. ${ }^{223}$ Chris Anderson has observed that the Maker Movement is a 'broad description that encompasses a wide variety of activities, from traditional crafting to high-tech electronics' ${ }^{224}$ The Maker Movement has been a strong advocate of the recognition of a right to repair. The Maker's Bill of Rights has emphasized that 'ease of repair shall be a design ideal, not an afterthought'.225

iFixit's Repair Manifesto has stressed that 'repair is better than recycling', 'repair saves you money', 'repair teaches engineering', and 'repair saves the planet'. ${ }^{226}$ iFixit made a submission to the Productivity Commission's inquiry

https://www.eff.org/deeplinks/2020/11/ink-stained-wretches-battle-soul-digital-freedom-taking-placeinside-your-printer (accessed 1 August 2021).

223 On the Maker Movement, see Anderson (n 23); Hatch (n 23); Dougherty with Conrad (n 23); Gershenfeld et. al (n 23); Hatch (n 23).

${ }^{224}$ Anderson (n23) 20.

${ }^{225}$ Torone (n 22).

${ }^{226}$ TechCrunch (n 22); iFixit (n 22). 
into the right to repair in Australia. ${ }^{227}$ The submission outlines the collective identity of the organisation:

iFixit is an international, open-source, online repair manual for everything. Our mission is to provide people with the knowledge they need to make their things work for as long as possible. We represent a global community of makers, tinkerers, fixers, and repair professionals. In 2020, the iFixit community taught repair to over 100 million people from almost every country in the world, including over 4 million Australians. Our strongly collaborative group has published over 70,000 repair guides on everything from home appliances to automobiles to smartphones. This massive, free resource has helped people fix everything from cellphones and game consoles to tractors and musical instruments. ${ }^{228}$

The organisation also discusses its role in advocacy: 'iFixit stands firm in its support of the tinkerers and independent repair professionals in our community.' 229 iFixit emphasizes: 'We believe that owners should have the right to repair, modify, and tinker with the things they own, and that they should be able to access repair services of their own choosing' ${ }^{230}$ The civil society organisation observed: 'iFixit has made it our business to provide access to the service manuals, troubleshooting diagrams, and parts supply chains that most product manufacturers used to provide, but that many no longer do. ${ }^{231}$ iFixit stressed that the repair, refurbishing, and remanufacturing 'sectors diversify the

227 iFixit, 'Re: Response to Request for Information from the Australian Productivity Commission', Submission 107 to the Issues Paper of the Productivity Commission, 1 February 2021, available at https://www.pc.gov.au/ data/assets/pdf file/0005/272696/sub107-repair.pdf (accessed 1 August 2021).

${ }^{228}$ Ibid.

${ }^{229}$ Ibid.

${ }^{230}$ Ibid.

${ }^{231}$ Ibid. 
economy, adding jobs and businesses, while fostering entrepreneurship and innovation.' ${ }^{232}$ The Right to Repair movement has sought to develop a more sustainable and equitable circular economy. ${ }^{233}$

There has been increasing academic and scholarly interest in the topic of intellectual property and 3D printing. ${ }^{234}$ There has also been significant interest in the public policy dimensions of the topic. ${ }^{235}$ Some scholars, such as Mark Lemley, have argued that patent law, practice, and policy will be disrupted by 3D printing, additive manufacturing, and digital fabrication. ${ }^{236}$ Others, such as Geertrui van Overwalle, have argued that patent law has a long accommodated emerging technologies, and will be able to assimilate 3D printing into its schema. $^{237}$

232 Ibid.

${ }^{233}$ John Wackman and Elizabeth Knight, Repair Revolution: How Fixers are Transforming Our Throwaway Culture (New World Library 2020); Sandra Goldmark, Fixation: How to Have Stuff Without Breaking the Planet (Island Press 2020).

${ }^{234}$ John Hornick, 3D Printing will Rock the World (Createspace 2015); Angela Daly, Socio-Legal Aspects of the 3D Printing Revolution (Palgrave Macmillan 2016); Dinusha Mendis, Mark Lemley, and Matthew Rimmer (ed.), 3D Printing and Beyond: Intellectual Property and Regulation (Edward Elgar 2019); Osborn (n 163); James Griffin, The State of Creativity: The Future of 3D Printing, 4D Printing and Augmented Reality (Edward Elgar 2019); Hing Kai Chan, Hui Leng Choo, Onyeka Osuji and James Griffin (ed.), Intellectual Property Rights And Emerging Technology: 3D Printing in China (Routledge 2019).

${ }^{235}$ Michael Weinberg, 'It Will be Awesome if They Don't Screw it Up: 3D Printing, Intellectual Property, and the Fight Over the Next Great Disruptive Technology' (Public Knowledge, 2012), available at https://www.publicknowledge.org/files/docs/3DPrintingPaperPublicKnowledge.pdf (accessed 1 August 2021); Michael Weinberg, 'What's the Deal with Copyright and 3D Printing?' (Public Knowledge, January 2013), available at https://www.publicknowledge.org/newsblog/blogs/whats-the-deal-with-copyright-and-3d-printing (accessed 1 August 2021); Michael Weinberg, '3D Scanning: A World Without Copyright' (Shapeways, 2016), available at http://www.shapeways.com/wordpress/wp-content/uploads/2016/05/white-paper-3d-scanning-worldwithout-copyright.pdf (accessed 1 August 2021).

${ }^{236}$ Mark Lemley, 'IP in a World without Scarcity' (2015) 90 (2) New York University Law Review 461.

${ }^{237}$ Geertrui Van Overwalle and Reinout Leys, '3D Printing and Patent Law: A Disruptive Technology Disrupting Patent Law?' (2017) 48 (5) International Review of Intellectual Property and Competition Law 504. 


\subsection{Australia}

In the context of the topic of repair, UNSW scholar Miles Park has written about how 3D printing and additive manufacturing have been deployed in respect of making replacement parts. ${ }^{238}$ He observes that 3D printing could transform how products are designed, manufactured, distributed, and sold:

3D printing replacement parts demonstrates an evolutionary step towards this transformation. It offers the opportunity to extend product lifespans by providing re-printable replacement parts when existing part inventories are exhausted, or no longer exist. The technology enables the repositioning of production both in terms of location (printing parts in places where they are required) and structure (by placing the tools of production in the hands of the consumer). ${ }^{239}$

Park predicts that '3D printing will continue to rapidly improve and will become increasingly prolific in mainstream consumer markets'. ${ }^{240} \mathrm{He}$ notes: 'The technology will become more affordable for individual ownership and will be easier to use.' ${ }^{241}$ Park is hopeful that 'technical and regulatory obstacles will eventually be resolved that will contribute to the acceptance by manufacturing brands to provide 3D print information and parts, and consumer confidence to obtain 3D printed replacement parts. ${ }^{242}$

In its Draft Report, the Productivity Commission considered the advent of 3D printing, and its current and future relevance to the right to repair: 'New technologies such as 3D printing (and other forms of "additive manufacturing"',

\footnotetext{
${ }^{238}$ Miles Park, 'Printer to Repair: 3D Printing and Product Repair', in Jonathan Chapman (ed.), Routledge Handbook of Sustainable Product Design (Routledge 2017), 236-259.

239 Ibid 237.

240 Ibid 248.

${ }^{241}$ Ibid 248.

242 Ibid 248.
} 
whereby objects are created by adding layers of material, rather than by removing material, may also increase the accessibility of spare parts, by enabling repairers to fabricate their own replacement parts and be less dependent on conventional manufacturers. ${ }^{243}$ At a speech at the National Repair Summit, Commissioner Paul Lindwall observed: 'The increasing use of 3D printing may provide a less costly way of providing spare parts in the future - just as we now see print on demand for rarely purchased books.' 244

There was a range of evidence to the Productivity Commission on the impact of 3D printing on repair. At the Productivity Commission, Kyle Wiens from iFixit acknowledged that while 3D printing could be a solution, it would not be a practical one for some tech-based products: '3D printing is a wonderful idea ... we do have some 3D printed models on iFixit ... unfortunately, in our analysis of parts, about $2 \%$ of all parts can be 3D printed with current technology ... where $3 \mathrm{D}$ printing is more compelling and interesting is in whitegoods. ${ }^{245}$

At the public hearing, the Australian Academy of Technology and Engineering observed that $3 \mathrm{D}$ printing and additive manufacturing would become more commonplace, especially with the materials revolution. ${ }^{246}$

${ }^{243}$ Productivity Commission, 'Right to Repair: Draft Report' (n 20).

${ }^{244}$ Commissioner Paul Lindwall, 'The Right to Repair Draft Report', Productivity Commission, Australian Repair Summit, Canberra, 9 July 2021, available at https://www.pc.gov.au/newsmedia/speeches/repair (accessed 1 August 2021).

${ }^{245}$ Aimee Chanthadavong, 'iFixit CEO Names and Shames Tech Giants for Right to Repair Obstruction' (ZDNet, 19 July 2021), available at https://zd.net/3kyA3Z9 (accessed 1 August 2021).

246 Australian Academy of Technology and Engineering, 'Productivity Commission Inquiry into the Right to Repair', Public Hearing, Canberra, 21 July 2021, available at https://www.pc.gov.au/inquiries/current/repair/public-hearings (accessed 1 August 2021). 
Dr Muhammad Zaheer Abbas observed that repair with the help of 3D printing technologies was critically important for medical technologies during the COVID-19 crisis. $^{247}$

Nonetheless, in its final report, the Productivity Commission downplayed whether 3D printing would face intellectual property infringement issues in Australia:

\begin{abstract}
In Australia, the use of 3D printing to create spare parts is unlikely to infringe manufacturers' IP rights if: the 3D printed spare part is not substantially similar in overall impression to the original part (or the 'spare parts defence' under the Designs Act applies; there has been no copying of the part's original (copyrighted) design schematics in the creation of the print (the part is reverse engineered); and no manufacturer trademarks are printed on to the part $^{248}$
\end{abstract}

However, to the author, this statement highlights the lack of harmonisation between Australia's intellectual property regimes in respect of dealing with repair. Moreover, this statement also underlines the uncertainty faced by 3D printing manufacturers and users in using additive manufacturing for the purposes of repair.

\title{
4.2 United States
}

In the United States, there has been an application of 3D printing and additive manufacturing for repair purposes in an array of fields.

\footnotetext{
${ }^{247}$ Muhammad Zaheer Abbas, 'Patent Law and 3D Printing Applications in Repairing Medical Equipment', Submission to the Productivity Commission Inquiry into the Right to Repair in Australia, January 2021, available at https://www.pc.gov.au/_data/assets/pdf file/0006/272292/sub034-repair.pdf (accessed 1 August 2021).

${ }^{248}$ Productivity Commission, 'Right to Repair: Inquiry Report No. 97' (n 20) 167.
} 
Kelsey Wilbanks has considered how 3D printing will fare in the United States given past patent precedents on the right to repair. ${ }^{249}$ Wilbanks observes that 'some patent holders will start to attribute lost revenues to the 3D printing revolution, and they will view 3D printing replacement parts as theft. ${ }^{\prime 250}$ Wilbanks comments: 'As a result, they will either try to tighten the restrictions on the products they sell, or they will initiate litigation against the consumers who are fixing products with multiple 3D printed replacement parts.' ${ }^{251}$

Wilbanks reflects that 'current patent law holds that a consumer has a legal right to repair a patented combination, but not the right to reconstruct it.' ${ }^{252}$ He laments, though, the lack of a bright-line rule about the difference between repair and reconstruction: 'The Supreme Court has declined to create an allencompassing test to determine the difference between permissible repair and infringing reconstruction, and as a result lower courts have applied the law inconsistently and erratically'. ${ }^{253}$ Wilbanks maintains that there is a need to remedy this uncertainty in the law: 'Consumers need and deserve a defined standard or set of standards to determine whether their actions are permissible repair or infringing reconstruction'. ${ }^{254}$ The author submits that 'an "all or nothing" standard, a redefined burden-shifting analysis, or a multifactor approach would help lessen the ambiguities in the current repair-reconstruction legal doctrine. ${ }^{255}$

\footnotetext{
${ }^{249}$ Kelsey Wilbanks, 'The Challenges of 3D Printing to the Repair-Reconstruction Doctrine in Patent Law' (2013) 20 George Mason Law Review 1147.

${ }^{250}$ Ibid.

${ }^{251}$ Ibid.

252 Ibid.

253 Ibid.

${ }^{254}$ Ibid.

${ }^{255}$ Ibid.
} 
Wilbanks concludes: 'As 3D printing technology advances, the legal standards distinguishing item repair and reconstruction must do the same. ${ }^{256}$ However, there could be further complications - particularly if individual parts are subject to patent protection in their own right.

On a more practical level, the academic and repairer Sandra Goldmark comments that $3 \mathrm{D}$ printing repair requires access to repair information: 'While 3D printing is great technology, until manufacturers make all the parts drawings for their products easily available - or just plain make the parts available - it's not really practical, especially since each repair is different.'257

Professor Mark Lemley and Professor Mark McKenna have expressed concern about intellectual property owners targeting independent repairers. ${ }^{258}$ They have maintained: 'The law shouldn't prevent new entrants from disrupting existing incumbents without good reason.' 259

In his landmark book, The Right to Repair, Professor Aaron Perzanowski comments that there are outstanding issues in respect of patent law and the right to repair. ${ }^{260}$ The scholar observes: 'Even where courts embrace the right of owners to replace or repair components, patent law can still impede repair. ${ }^{\prime 261}$ He commented: 'If the components themselves are patented, their production, sale, and use are still subject to the exclusive rights of patent holders' ${ }^{262}$ Perzanowski warned that patent holders 'can use that power to starve repair providers of the replacement parts they need or charge exorbitant prices that

\footnotetext{
256 Ibid.

257 Goldmark (n 233).

258 Mark Lemley and Mark McKenna, 'Unfair Disruption' (2020) 100 Boston University Law Review 71.

259 Ibid 131.

260 Perzanowski (n 9) 124-132.

261 Ibid 132.

262 Ibid 132.
} 
discourage third-party repairs. ${ }^{263}$ He specifically raised the risk of 3D-printing users facing patent infringement lawsuits: 'Nothing in patent law would prevent a more mercenary device maker from pursuing such a claim.' ${ }^{264}$

\subsection{Canada}

There has been much interest in the right to repair in Canada. The Competition Bureau Canada has investigated legal issues in respect of the durability and repairability of goods. ${ }^{265}$ Civil society organisations such as Open Media have lobbied for a broader protection of the right to repair. ${ }^{266}$

Tesh Dagne and Gosia Piasecka have considered the right to repair doctrine and the use of 3D printing technology under Canadian patent law. ${ }^{267}$ They anticipated clashes between intellectual property holders, 3D printing companies, and consumers:

There is an increasing trend to share the designs for these 3D printed creations online, as consumers progressively shift away from vertical economies towards horizontal market networks. This trend is commonly referred to as the sharing economy. It presents a wealth of opportunities but also bears challenges. As consumers want to have greater freedom and autonomy over the design and manufacture of goods, patent-holders will seek to minimize the unauthorized reconstruction of their inventions. ${ }^{268}$

\footnotetext{
${ }^{263}$ Ibid 132.

${ }^{264}$ Ibid 132.

${ }^{265}$ Competition Bureau Canada, 'Summary of the Brief Presented to the Office of Consumer Protection on the Durability and Reparability of Goods' (20 January 2022), available at https://www.competitionbureau.gc.ca/eic/site/cb-bc.nsf/eng/04534.html (accessed 1 August 2021).

266 Open Media, 'Right to Repair', available at https://action.openmedia.org/page/52791/petition/1?locale=en-US (accessed 1 August 2021).

${ }^{267}$ Tesh Dagne and Gosia Piasecka, 'The Right to Repair Doctrine and the Use of 3D Printing Technology in Canadian Patent Law' (2016) 14 Canadian Journal of Law and Technology 263.

268 Ibid 263.
} 
The lawyers argued: 'Due to its innovative nature and connection to the sharing economy, 3D printing is bound to disrupt today's manufacturing markets' ${ }^{269}$ However, they maintained that the existing regimes of intellectual property were not well designed to deal with 3D printing and additive manufacturing. In their view, there was a need to introduce an all-encompassing right to repair, subject to a number of conditions: 'It is vital to balance the interests of patent-holders with innovative consumers, so 3D printing can thrive without eroding existing patent rights and investments by stakeholders' ${ }^{270}$

In 2021, the Parliament of Canada has been interested about law reform in respect of the right to repair because of a number of factors. ${ }^{271}$ Legislators have expressed the view that rural and regional communities would benefit from a right to repair - especially in far-flung regions of Canada. ${ }^{272}$ Canadian politicians have commented that a right to repair would enhance consumer rights and competition policy. ${ }^{273}$ Small business would be beneficiaries of a right to repair. ${ }^{274}$ The recognition of a right to repair would also boost product stewardship and sustainable development. ${ }^{275}$ Policy-makers have emphasized that a right to repair would helpful - given that the coronavirus public health crisis has disrupted supply chains in various ways.

\footnotetext{
${ }^{269}$ Ibid 286.

${ }^{270}$ Ibid 286.

${ }^{271}$ Bill C-272 (n 151); The Hon. Bryan May, 'Private Members Business', Hansard, Parliament of Canada, 15 April 2021, available at https://www.ourcommons.ca/DocumentViewer/en/432/house/sitting-81/hansard\#11239176 (accessed 1 August 2021).

272 The Hon. Jeremy Patzer, 'Copyright - Private Member's Business', Hansard, Parliament of Canada, 15 April 2021, available at https://www.ourcommons.ca/DocumentViewer/en/432/house/sitting-81/hansard\#11239216 (accessed 1 August 2021).

273 The Hon. Brian Masse, 'Copyright - Private Member's Business', Hansard, Parliament of Canada, 15 April 2021, available at https://www.ourcommons.ca/DocumentViewer/en/432/house/sitting-81/hansard\#11239243 (accessed 1 August 2021).

274 The Hon. Sebastien Lemire, 'Copyright - Private Member's Business', Hansard, Parliament of Canada, 15 April 2021, available at https://www.ourcommons.ca/DocumentViewer/en/432/house/sitting-81/hansard\#11239225 (accessed 1 August 2021).

275 May (n 271).
} 
Anthony Rosborough has argued that a greater degree of federalprovincial co-operation is needed to address the multiplicity of laws which touch upon repair. ${ }^{276}$

\subsection{United Kingdom}

As discussed previously, United Kingdom courts have been reluctant to recognise a free-standing right to repair. ${ }^{277}$

Nonetheless, there is a burgeoning Maker Movement in the United Kingdom - in England, ${ }^{278}$ Scotland, ${ }^{279}$ Wales, ${ }^{280}$ and Northern Ireland. ${ }^{281}$ There has been a community push for a recognition of the right to repair, with the issuance of The Manchester Declaration. ${ }^{282}$ The Manchester Declaration provides a clarion call for law reform: 'We ask UK legislators and decision-makers at all levels, as well as product manufacturers and designers, to stand with us for our Right to Repair, by making repair more accessible and affordable, and ensuring that we adopt product standards making products better supported, well documented and easier to repair by design.' ${ }^{283}$

In their study for the United Kingdom Intellectual Property Office, Dinusha Mendis and her colleagues wondered: 'What are the implications of

276 Anthony Rosborough, 'Toward a Canadian Right to Repair: Opportunities and Challenges' (2023) Berkeley Technology Law Journal, available at https://papers.ssrn.com/sol3/papers.cfm?abstract_id=4236843 (accessed 1 January 2023).

277 Schütz (UK) Limited $v$ Werit UK Limited, Protechna SA [2010] EWHC 660 (Pat).

${ }^{278}$ United Kingdom Makerspaces, available at https://www.nesta.org.uk/archive-pages/ukmakerspaces-the-data/ (accessed 1 August 2021).

279 Make Works Scotland, https://make.works/scotland/about/\#overview (accessed 1 August 2021)

${ }^{280}$ Business Wales, 'Ffiws - Maker Space', available at https://businesswales.gov.wales/walesruralnetwork/local-action-groups-and-projects/projects/ffiwsmaker-space (accessed 1 August 2021).

281 Pip Shea and Xin Gu, 'Makerspaces and Urban Ideology: The Institutional Shaping of Fab Labs in China and Northern Ireland' (2018) 12 The Journal of Peer Production 78.

282 The Manchester Declaration (6 October 2018), available at https://manchesterdeclaration.org/ (accessed 1 August 2021).

283 Ibid. 
consumers and independent repair companies being able to manufacture spare parts for domestic appliances on demand, using consumer 3D Printers?' ${ }^{284}$

Her second report with Phil Reeves considers 3D printing and replacement parts amongst other things. Mendis and Reeves consider the automotive aftermarket for printing parts. ${ }^{285}$ They contended that '[additive manufacturing] could be used to make component parts for the automotive industry directly from digital design files, rather than high cost fixed assets such as injection moulding, rotational moulding and die casting tooling ${ }^{\prime 286}$ Mendis and Reeves were nonetheless sceptical of the speed of uptake of 3D printed replacement parts in the automotive industry: 'Given the speed of [additive manufacturing] technology development it is very unlikely for there to be significant revenue opportunities in this sector for at least the next 15-years. ${ }^{287}$ They suggested that there would be a longer-process of standard-setting, which would take place first.

Mendis and Reeves also look at the domestic appliances aftermarket using home-based 3D printing: 'Although the idea of printing spare parts at home for domestic appliances appears to hold much promise, and to a small extent is already taking place today, it is believed that it will be a substantial period of time before this becomes a widespread practice. ${ }^{288}$

${ }^{284}$ Dinusha Mendis, Davide Secchi, and Phil Reeves, 'A Legal and Empirical Study into the Intellectual Property Implications of 3D Printing' (United Kingdom Intellectual Property Office, March 2015), https://www.gov.uk/government/uploads/system/uploads/attachment_data/file/421222/A_Legal_and_ Empirical_Study_into_the_Intellectual_Property_Implications_of_3D_Printing_-_Exec_Summary_Web.pdf (accessed 1 August 2021).

285 Phil Reeves and Dinusha Mendis, 'The Current Status and Impact of 3D Printing Within the Industrial Sector: An Analysis of Six Case Studies' (United Kingdom Intellectual Property Office, 2015),

https://assets.publishing.service.gov.uk/government/uploads/system/uploads/attachment_data/file/549 046/Study-2.pdf (accessed 1 August 2021).

286 Ibid 14.

287 Ibid 21.

${ }^{288}$ Ibid 25. 


\subsection{European Union}

In the European Union, there are a well-established network of Fab Labs. ${ }^{289}$ Peter Troxler contends that the Fab Lab Model tackles 'obsolescence' through providing 'competition from the diffusion of cheap digital fabrication technologies'. ${ }^{290} \mathrm{He}$ comments that the Fab Lab Maker Movement seeks to 'expose corporate strategies, among them design for obsolescence, the notion that you don't own a product if you can't open it, and the quest to repair broken goods'. ${ }^{291}$ iFixit Europe has provided advocacy for a right to repair in the European Union. ${ }^{292}$ In 2020, the European Parliament called for the European Commission to 'develop and introduce mandatory labelling, to provide clear, immediately visible and easy-to-understand information to consumers on the estimated lifetime and reparability of a product at the time of purchase' ${ }^{293}$ France has introduced a new scheme for labelling repairability as well. ${ }^{294}$

Looking at the European Union, Rosa Ballardini and her colleagues have also explored some of the legal and business challenges in respect of printing spare parts through $3 \mathrm{D}$ printing and additive manufacturing. ${ }^{295}$ As the work of

${ }^{289}$ Massimo Menichinelli (ed.), Fab Lab: Revolution Field Manual, (Niggli, Braun Publishing AG 2017).

${ }^{290}$ Peter Troxler, 'What is a Fab Lab For?', in Menichinelli (n 289) 52.

291 Ibid 56.

292 iFixit Europe, available at https://eustore.ifixit.com/ (accessed 1 August 2021).

${ }^{293}$ Kyle Wiens, 'European Parliament Votes for Right to Repair' (iFixit, 25 November 2020), available at https://www.ifixit.com/News/47111/european-parliament-votes-for-right-torepair\#: : text=In $\% 20 \mathrm{a} \% 20$ landmark $\% 20$ move $\% 2 \mathrm{C} \% 20$ the, $94 \% 20$ against $\% 2 \mathrm{C} \% 20$ with $\% 20207 \% 20 \mathrm{a}$ bstentions(accessed 1 August 2021).

${ }^{294}$ Right to Repair, 'The French Repair Index: Challenges and Opportunities' (3 February 2021), available at https://repair.eu/news/the-french-repair-index-challenges-and-opportunities/ (accessed 1 August 2021); Maddie Stone, 'Why France's new 'repairability index' is a big deal' (Grist, 8 February 2021), available at https://grist.org/climate/why-frances-new-repairability-index-is-a-bigdeal/ (accessed 1 August 2021).

295 Rosa Maria Ballardini, Inigo Flores Ituarte, and Eujin Pei, 'Printing Spare Parts through Additive Manufacturing: Legal and Digital Business Challenges' (2018) 29 (6) Journal of Manufacturing Technology Management 958. 
the European Patent Office has shown, the patent landscape in respect of 3D printing has become very crowded. ${ }^{296}$ There has been a call for a greater emphasis in European intellectual property law upon considerations of sustainable development and the circular economy. ${ }^{297}$

In their 2017 Springer brief on design protection of visible spare parts, Dana Beldiman and Constantin Blanke-Roeser considered the future of spare parts in an age of 3D printing. ${ }^{298}$ They foresee that additive manufacturing will become much more widespread:

3D printing technology will undoubtedly find widespread application in the automotive industry, in particular the spare parts industry. Of course, mass production of spare parts is still several years away, estimated in the range of 10-15 years. Once established however, the technology will profoundly change the mode of industrial production, as well as the market structure and the relative positions of its players. ${ }^{299}$

The scholars debate what impact 3D printing will have on spare parts, and how intellectual property will respond to such matters. Beldiman and Blanke-Roeser concluded: 'It is more likely that OEM's will take advantage of the numerous smaller local players to enter co-operative arrangements that allow localized, on demand supply of spare parts. ${ }^{\prime 300}$

${ }^{296}$ European Patent Office, 'Patents and Additive Manufacturing: Trends in 3D Printing Technologies' (European Patent Office, 2020), available at http://documents.epo.org/projects/babylon/eponet.nsf/0/C2F0871212671851C125859F0040BCCA/\$F ILE/additive_manufacturing_study_en.pdf (accessed 1 August 2021).

${ }_{297}$ Taina Pihlajarinne, 'European Steps to the Right to Repair: Towards a Comprehensive Approach to a Sustainable Lifespan of Products and Materials?' (2020) 31 Australian Intellectual Property Journal 111; Ole-Andreas Rognstad and Inger B. Ørstavik (ed.), Intellectual Property and Sustainable Markets (Edward Elgar 2021).

298 Dana Beldiman and Constantin Blanke-Roeser, An International Perspective on Design Protection of Visible Spare Parts (Springer Briefs in Law 2017).

299 Ibid 115.

${ }^{300}$ Ibid 128. 


\subsection{The Right to Repair and the Future of Advanced Manufacturing}

In his survey of 3D Printing and Intellectual Property, Lucas Osborn recognises that 'IP law will face many calls for change from a variety of constituencies' in the face of $3 \mathrm{D}$ printing and additive technologies. ${ }^{301} \mathrm{He}$ has urged that there be further debate about the field: 'Continuing the study and conversation will be immensely important to achieving a society in which 3D printing technology, innovation, and creativity can optimally flourish. ${ }^{302}$

There has been a concern about intellectual property owners engaging in profiteering in the fields of 2D printing and 3D printing. ${ }^{303}$ This literature review of scholarly work and public policy inquiries has shown that there has been a strong impetus to redesign intellectual property laws to better to take into account new technologies such as 3D printing and additive manufacturing, and the cultures of the Maker Movement and right-to-repair advocates. The development of $4 \mathrm{D}$ printing also raises further issues in respect of the right to repair. Skylar Tibbits of the Self-Assembly Lab at MIT has discussed how the materials revolution may promote recycling, reuse, repair and even self-repair. ${ }^{304}$

In advanced manufacturing, the robotics revolution is also raising complex questions in respect of repair. There is a lawsuit on foot on the United States, contending that a monopoly over surgical robots has had an anticompetitive impact upon healthcare in hospitals. ${ }^{305}$ The right to repair may also

\footnotetext{
301 Osborn (n 163) 228.

302 Ibid 229.

${ }^{303}$ Doctorow (n 222).

304 Skylar Tibbits, Things Fall Together: A Guide to the New Materials Revolution, (Princeton University Press 2021). See also Skylar Tibbits, Self-Assembly Lab: Experiments in Programming Matter, (Routledge 2016); Skylar Tibbits (ed.), Autonomous Assembly: Designing for a New Era of Collective Construction (John Wiley \& Sons 2017).

305 Bob Herman, 'Hospitals are Taking on a Surgical Robot "Monopoly"' (Axios, 13 July 2021), available at https://www.axios.com/hospitals-are-taking-on-a-surgical-robot-monopoly-57b3d 230 eff3-49a6-8300-4340bd8cee1f.html (accessed 1 August 2021).
} 
be important to ensure that the Internet of Things does not become an Internet of Broken Things. ${ }^{306}$

\section{Conclusion}

As informed by the Productivity Commission inquiry, the new Albanese Government has an opportunity to make some transformative Australian law reform in respect of the right to repair. The assistant Minister for Competition, the Hon. Andrew Leigh MP, has promised to boost competition in the repair sector: 'We can achieve this by ensuring big technology companies cannot create monopolies that allow them to profiteer at the expense of Australians. ${ }^{307} \mathrm{He}$ observed: 'This means protecting Australians' "right to repair", which gives households and businesses the ability to have their products repaired at a competitive price using a repairer of their choice.' ${ }^{308}$ Leigh has noted: 'There are opportunities to further reduce barriers to repair for products in some markets, and the Australian Government wants to pursue reforms that are evidence-based and target sectors where it will be most beneficial. ${ }^{\prime 309}$

In this context, this paper has contended that there is a need to expand and widen the objectives of Australia's patent system to better reflect some of the principles and concerns in play on the topic of the right to repair. It has offered an analysis of the dispute in the case of Calidad Pty Ltd $v$ Seiko Epson Corporation. While critical of the approach taken by the Federal Court of Australia and the Full Court of Australia, this paper is relieved by the position of the majority of the High Court of Australia in respect of the patent exhaustion theory. It was also

\footnotetext{
306 Cory Doctorow, 'An Internet of Things That Do as They're Told' (YouTube, 8 June 2015), available at https://www.youtube.com/watch?v=ACwRGLbFY_M (accessed 1 August 2021).

${ }^{307}$ Leigh (n 8).

308 Ibid.

${ }^{309}$ Ibid.
} 
pleasing to see that even the minority of the High Court of Australia were concerned about the status of repairs in patent infringement proceedings. In spite of the progress on judicial recognition of patent exhaustion in Australia, this paper has argued that there is a need for further patent law reform to provide recognition of a right to repair. It is debated as to whether this is best dealt with through the interpretation of patent infringement (drawing a distinction between repair and reconstruction); the development of a stand alone defence for the right to repair (like the spare parts defence in designs law); or the utilisation of devices, such as compulsory licensing and crown use, which are designed to promote competition policy and the wider public interest. There is also a need to ensure that intellectual property holders cannot contract out of any repair exceptions in Australia. This paper has maintained that there is an urgent need to reform patent law - particularly in light of recent developments in respect of 3D printing, additive manufacturing, and digital fabrication. Patent law needs to be welladapted for what has been described as the fourth Industrial Revolution. Indeed, the regime should seek to provide legal recognition for some of the ideals enunciated in the Maker's Bill of Rights, and the iFixit Repair Manifesto. ${ }^{310}$

As highlighted by the work of Dan Burk and Mark Lemley, patent law espouses a theory of technology neutrality, but in practice it is often contextual in its operation in particular technological fields. ${ }^{311}$ That is certainly evident in the debate over patent law and the right to repair. In the area of automobiles, there has been a longstanding debate over the right to repair. ${ }^{312}$ In the field of agriculture, there has been an increasing concern about the right to repair in

\footnotetext{
310 Torone (n 22); TechCrunch (n 22); iFixit (n 22).

311 Dan Burk and Mark Lemley, The Patent Crisis and How the Courts Can Solve It (The University of Chicago Press 2009).

312 Treasury (n 2); Competition and Consumer Amendment (Motor Vehicle Service and Repair Information Sharing Scheme) Act 2021 (Cth); Sukkar (n 2).
} 
respect of tractors and other agricultural machinery. United States farmers have been pushing for a right to repair. ${ }^{313}$ Competition expert David Doyen has observed: 'An entire network of underground hacking and a "right to repair" movement have emerged to fight the tractor monopoly'. ${ }^{314}$ Indeed, Senator Elizabeth Warren vowed to legislate for a right to repair for farm machinery, during her Presidential campaign. ${ }^{315}$ President Joe Biden has issued an executive order, which specifically focuses on the right to repair in the field of agriculture. ${ }^{316}$ The ACCC has been inquiring into the topic of the right to repair in agricultural markets. ${ }^{317}$ The National Farmers Federation has highlighted major barriers in terms of the Australian repair market. ${ }^{318}$ In its draft report, Productivity Commission has maintained that there is a need for action in respect

313 Adam Minter, 'U.S. Farmers Are Being Bled by the Tractor Monopoly' (Bloomberg Opinion, 23 April 2019), available at https://www.bloomberg.com/opinion/articles/2019-04-23/u-s-farmers-needa-better-way-to-fix-their-tractors (accessed 1 August 2021); Adam Betz, 'Farm Bureau Members ratchet up "Right-to-Repair" Pressure' (Star Tribune, 4 February 2020), available at https://www.startribune.com/farm-bureau-members-ratchet-up-right-to-repair-pressure/567459262/ (accessed 1 August 2021).

314 Dayen (n 194) 55.

315 Elizabeth Warren, 'Leveling the Playing Field for America's Family Farmers' (Medium, 27 March 2019), available at https://medium.com/@teamwarren/leveling-the-playing-field-foramericas-family-farmers-823d1994f067 (accessed 1 August 2021).

316 The White House (n 197).

317 Australian Competition and Consumer Commission, 'Agricultural Machinery: After-Sales Markets, Discussion Paper' (Australian Competition and Consumer Commission, 2020), available at https://consultation.accc.gov.au/agriculture/agricultural-machinery-discussion-paper/ (accessed 1 August 2021); Jemima Burt, "'Right To Repair" Regulation Necessary, Say Small Businesses and Environmentalists' (ABC Capricornia, 3 March 2019), available at https://www.abc.net.au/news/2019-03-03/does-australia-need-a-right-to-repair/10864852 (accessed 1 August 2021); Annie Guest, 'Right to Repair: Farmers Demand the Right to Repair their Own Machinery' (ABC Landline, 16 May 2020), available at https://abc.net.au/landline/right-to-repair:farmers-demand-the-right-to/12256266 (accessed 1 August 2021); Kit Mochan, “"Right to Repair” Taken up by the ACCC in Farmers' Fight to Fix their Own Tractors' (ABC News, 19 April 2020), available at https://www.abc.net.au/news/2020-04-19/right-to-repair-tractors-taken-up-by-theaccc/12156196 (accessed 1 August 2021).

318 The National Farmers Foundation, 'Re: Submission to the Productivity Commission "Right to Repair" Inquiry', Submission 55 to the Issues Paper, Productivity Commission, 1 February 2021, available at https://www.pc.gov.au/_data/assets/pdf_file/0004/272335/sub055-repair.pdf (accessed 1 August 2021). 
of repair restrictions in rural and regional communities in Australia. ${ }^{319}$ The final report of the Productivity Commission has highlighted a range of sectors, in which repair restrictions are a major, pressing issue. ${ }^{320}$

In the domain of information and communications technology and electronics, there has been debate over the right to repair - particularly with Apple's products. Upset at the behaviour of Apple, Apple Co-Founder Steve Wozniak has expressed his support for the right to repair campaign. ${ }^{321} \mathrm{He}$ reflected: 'We wouldn't have had an Apple had I not grown up in a very open technology world.' ${ }^{322}$ The computer engineer noted: 'I wasn't restricted from anything that kept me from building that computer and showing the world that the future of personal computers is going to be a keyboard and a TV.' ${ }^{323}$ Wozniak said he relied upon repair: 'That all came from being able to repair things, and modify them, and tap into them yourself.' ${ }^{324}$ He recalled: 'You could repair a lot of things at low cost - but it's even more precious to know that you did it yourself. ${ }^{325}$ In light of such heritage, Wozniak questioned why Apple has been engaged in disputes with independent repairers: 'Why stop the self-repair community?' ${ }^{326}$ Wozniak lamented: 'Companies inhibit [the right to repair] because it gives the companies power, control, over everything.' ${ }^{327} \mathrm{He}$ maintained: 'It's time to start doing the right things. ${ }^{328}$ Wozniak concluded: 'It's

\footnotetext{
319 Productivity Commission, 'Right to Repair: Draft Report' (n 20).

${ }^{320}$ Productivity Commission, 'Right to Repair: Inquiry Report No. 97' (n 20).

${ }^{321}$ BBC News, 'Apple Founder Steve Wozniak Backs Right-to-Repair Movement' (BBC News, 9 July 2021), available at https://www.bbc.com/news/technology-57763037 (accessed 1 August 2021).

322 Ibid.

${ }^{323}$ Ibid.

${ }^{324}$ Ibid.

${ }^{325}$ Ibid.

326 Ibid.

327 Ibid.

${ }^{328}$ Ibid.
} 
time to recognise the right to repair more fully.' ${ }^{329}$ This call of support by Wozniak for the right to repair has received significant media attention especially given Apple's litigation and public policy lobbying against the right to repair. ${ }^{330}$ Wozniak made the final point: 'Is it your computer [as the customer]? or is it some company's computer?' ${ }^{331}$ Wozniak said. 'Think about that. It's time to start doing the right thing. ${ }^{332}$ For its part, considering mobile phones and tablets, the Productivity Commission was of the view that, 'while any harm may be small per consumer, the ubiquitous nature of mobile phones and tablets could mean that this adds up to significant harm across the economy.' ${ }^{333}$

With the COVID-19 outbreak, there has been a focus on the repair of essential medical equipment - such as ventilators. ${ }^{334}$ Professor Jorge Contreras from the University of Utah has argued: 'In order to permit needed repairs and

329 Ibid.

${ }^{330}$ Michelle Toh, 'Apple Co-founder Steve Wozniak: 'It's Time to Recognize the Right to Repair' (CNN, 9 July 2021), available at https://edition.cnn.com/2021/07/09/tech/apple-steve-wozniak-rightto-repair-intl-hnk/index.html (accessed 1 August 2021); Aimee Chanthadavong, 'Apple Cofounder Steve Wozniak Voices Support for Right to Repair' (ZDNet, 9 July 2021), available at https://www.zdnet.com/article/apple-co-founder-steve-wozniak-voices-support-for-right-to-repair/ (accessed 1 August 2021); Derek Wise, 'Apple Co-founder Steve Wozniak Stands Up for Rightto-repair, Argues Company Built on Open Source' (9to5Mac, 7 July 2021), available at https://9to5mac.com/2021/07/07/apple-co-founder-steve-wozniak-stands-up-for-right-to-repairargues-company-built-on-open-source/ (accessed 1 August 2021).

${ }^{331}$ Luke Dormehl, 'Apple co-founder Steve Wozniak says it's 'time to recognize' right to repair' (Cult of Mac, 8 July 2021), available at https://www.cultofmac.com/747077/apple-co-founder-stevewozniak-says-its-time-to-recognize-right-to-repair/.

332 Ibid.

333 Productivity Commission, 'Right to Repair: Draft Report' (n 20).

334 Cory Doctorow, 'Right to Repair in Times of Pandemic' (Electronic Frontier Foundation, 19 March 2020), available at https://eff.org/deeplinks/2020/03/right-repair-times-pandemic (accessed 1 August 2021); Kathleen Bourke, 'COVID-19 Highlights Why IP Shouldn't Limit the Right to Repair' (Public Knowledge, 22 May 2020), available at https://publicknowledge.org/blog/covid-19highlights-why-ip-shouldnt-limit-the-right-to-repair/ (accessed 1 August 2021); Kyle Wiens, 'The Right to Repair Will Help Us Endure Outbreaks' (Wired, 5 March 2020), available at https://wired.com/story/opinion-the-right-to-repair-will-help-us-endure-outbreaks/ $\quad$ (accessed 1 August 2021). See also: Taylor Soper, 'Medical Device Repair Startup Summit Imaging fires back at Philips over Device "Hacking" Claims' (GeekWire, 20 June 2020), available at https://www.geekwire.com/2020/seattle-area-medical-device-startup-summit-imaging-fires-back-atphilips-in-lawsuit/ (accessed 1 August 2021). 
parts replacements for critical health-related equipment, courts should take a liberal view of the repair doctrine'.335 Oregon Senator Ron Wyden and representative Yvette Clarke introduced the Critical Medical Infrastructure Rightto-Repair Act 2020 (US) in order to address a number of these problems in the public health emergency. ${ }^{336}$ There has also been conflict over copyright access to manuals for the purpose of repair during the COVID-19 public health crisis. ${ }^{337}$ In the area of $3 \mathrm{D}$ printing and additive manufacturing, there has been a special interest in the use of technologies for the purposes of the repair of inventions otherwise protected by intellectual property. Medical technology companies, though, have demanded to be exempted from any right to repair regime. ${ }^{338}$ In its draft report, the Productivity Commission commented that 'although restrictions on repairs of medical equipment may generate some harm (particularly for any vulnerable or disadvantaged equipment users), this may not be sufficient to justify any policy response, due to elevated safety risks for some types of repair. ${ }^{339}$ In its final report, the Productivity Commission said that the topic of medical repairs required further investigation. ${ }^{340}$

335 Jorge Contreras, 'Patents and Coronavirus - The Right to Repair' (InfoJustice, 3 April 2020), available at http://infojustice.org/archives/42222 (accessed 1 August 2021); see also Jorge Contreras, 'Research and Repair: Expanding Exceptions to Patent Infringement in Response to a Pandemic' (2020) 7 (1) Journal of Law and the Biosciences, Isaa014, available at https://doi.org/10.1093/jlb/lsaa014 (accessed 1 August 2021).

${ }^{336}$ Critical Medical Infrastructure Right-to-Repair Act 2020 (S. 4473, H.R. 7956), available at https://www.congress.gov/bill/116th-congress/house-bill/7956/all-info (accessed 1 August 2021).

337 Kit Walsh, 'Medical Device Repair Again Threatened With Copyright Claims' (Electronic Frontier Foundation, 11 June 2020), available at https://eff.org/deeplinks/2020/06/medical-devicerepair-again-threatened-copyright-claims (accessed 1 August 2021); Kevin Truong, 'A Medical Device Maker Threatens iFixit Over Ventilator Repair Project' (Vice, 16 June 2020), available at https://www.vice.com/en us/article/akze8j/a-medical-device-maker-threatens-ifixit-over-ventilatorrepair-project (accessed 1 August 2021).

338 See for instance the submission of Medtronic Australia, 'Productivity Commission: Inquiry into the Right to Repair', Submission 186 to the Draft Report, Productivity Commission, July 2021, available at https://www.pc.gov.au/_ data/assets/pdf file/0004/279220/subdr186-repair.pdf (accessed 1 August 2021).

339 Productivity Commission, 'Right to Repair: Draft Report' (n 20).

${ }^{340}$ Productivity Commission, 'Right to Repair: Inquiry Report No. 97' (n 20) 144-146. 
It is important to remember, though, that the right to repair is not purely a technocratic matter of doctrinal matters in respect of intellectual property law. ${ }^{341}$ In addition to intellectual property law, a number of other legal disciplines and regulatory fields have been implicated by the right to repair. There has been a debate over the impact of contract law on the right to repair particularly around the topic of whether one cannot contract out of the right to repair. ${ }^{342}$ Under Australian consumer law, the ACCC has provided advice about repairs, and spare parts, and has taken action against companies in respect of the right to repair. ${ }^{343}$ Key consumer groups such as CHOICE Australia, the Consumer Action Law Centre, and the Productivity Commission have recommended a stronger consumer law regime. ${ }^{344}$ The right to repair raises larger questions about market monopolies, ${ }^{345}$ and the need for law reform of

${ }^{341}$ Christopher Heath and Anselm Kamperman Sanders (ed.), Spares, Repairs and Intellectual Property Rights (Kluwer Law International 2009).

${ }^{342}$ Derclaye (n 210).

343 Australian Competition and Consumer Commission, 'Repairs and Spare Parts', available at https://www.accc.gov.au/business/treating-customers-fairly/repairs-spare-parts (accessed 1 August 2021); Australian Competition and Consumer Commission, 'iPhone and iPad misrepresentations cost Apple Inc \$9 million in penalties', Press Release, 19 June 2018, available at https://www.accc.gov.au/media-release/iphone-and-ipad-misrepresentations-cost-appleinc-9-million-in-penalties (accessed 1 August 2021).

${ }^{344}$ CHOICE Australia, 'Submission to the Productivity Commission Issues Paper on the Right to Repair', Submission 126 to the Issues Paper, February 2021, https://www.pc.gov.au/ data/assets/pdf file/0013/273010/sub126-repair.pdf (accessed 1 August 2021); Josh Taylor, “Australian Warranties To "Discourage" Repairs or Replacements Under Consumer Law' (The Guardian, 20 July 2021), available at https://www.theguardian.com/law/2021/jul/20/australian-warranties-acting-to-discourage-repairs-orreplacements-under-consumer-law (accessed 1 August 2021); Consumer Action Law Centre, 'Right to Repair Inquiry' (15 February 2021), available at https://consumeraction.org.au/wpcontent/uploads/2021/02/210215-CALC-sub-Right-to-repair-FINAL.pdf (accessed 1 August 2021); Productivity Commission, 'Right to Repair: Draft Report' (n 20).

${ }^{345}$ Federal Trade Commission, 'Fixing the Nix: A Workshop on Repair Restrictions' (Federal Trade Commission, 16 July 2019), available at https://www.ftc.gov/news-events/events-calendar/nixing-fixworkshop-repair-restrictions (accessed 1 August 2021); Open Markets Institute, 'Fixing America: Breaking Manufacturers' Aftermarket Monopoly and Restoring Consumers' Right to Repair', White Paper, 13 April 2020, https://openmarketsinstitute.org/publications/fixing-america-breakingmanufacturers-aftermarket-monopoly-restoring-consumers-right-repair (accessed 1 August 2021). 
competition law and policy. ${ }^{346}$ There needs to be better oversight of anticompetitive abuses of intellectual property in Australia. ${ }^{347}$ The right to repair also raises issues about the relationship between intellectual property and sustainable development. There is a particular United Nations Sustainable Development Goal focused on responsible consumption and production. There is a need to ensure that intellectual property laws promote a circular economy. Moreover, environmental law has a role to play in the right to repair - particularly as it concerns the treatment of recycling and e-waste. As the ACT Attorney General Shane Rattenbury has made clear, the right to repair is also bound up with climate action - in terms of reducing the carbon footprint of our production and consumption. ${ }^{348}$ The topic of the right to repair requires intellectual property policy-makers, scholars, and lawyers to think about the linkages, intersections and connections of the discipline of intellectual property, with other fields of regulation - including consumer law, competition policy, sustainable development, environmental law, and climate law.

While this paper has presented an Australian story about the right to repair (one of many to be told), it is clear that there is a larger international debate over the right to repair. There has been a groundswell of support for the right to

\footnotetext{
${ }^{346}$ Valentine Korah, 'Antitrust Considerations: Refusal to License Intellectual Property in the U.S. and EC' in Christopher Heath and Anselm Kamperman Sanders (ed.), Spares, Repairs and Intellectual Property Rights (Kluwer Law International 2009), 183-206.

347 Jill McKeough, 'Is Intellectual Property Different, or Are All Unhappy Monopolists Similar?' (2003) 26 (1) UNSW Law Journal 289.

${ }^{348}$ Rattenbury (n 6).
} 
repair in the European Union; ${ }^{349}$ the Nordic nations; the United Kingdom; ${ }^{350}$ the United States; ${ }^{351}$ and Canada. ${ }^{352}$ There has been an increasing interest in the right to repair amongst developing countries - as part of making use of intellectual property flexibilities to better take into account the United Nations Sustainable Development Goals. ${ }^{353}$ There should be international action on the topic of intellectual property and the right to repair in relevant fora such as the World Intellectual Property Organization, the World Trade Organization, and the United Nations Development Programme.

${ }^{349}$ Igor Bonifac, 'EU Plans to Introduce Sweeping "Right to Repair" Legislation for Electronics' (Engadget, 11 March 2020), available at https://engadget.com/2020/03/11/eu-right-to-repair-phonestablets-computers/ (accessed 1 August 2021); Chloe Mikolajczak, 'The Circular Economy Blueprint paves the way for a Right to Repair in Europe' (Right To Repair Europe, 11 March 2020), available at https://repair.eu/news/circular-economy-action-plan// (accessed 1 August 2021); Pihlajarinne (n 297).

350 The Manchester Declaration 2018, available at https://manchesterdeclaration.org/ (accessed 1 August 2021); Tom Espiner and Rebecca Wearn, 'Right to Repair Rules will Extend Lifespan of Products, Government Says' (BBC News, 1 July 2021), available at https://www.bbc.com/news/business-57665593; (accessed 1 August 2021); Osborne Clark, 'UK Poised to Require "Right to Repair" Information for Consumers' (Lexology, 15 April 2021), available at https://www.lexology.com/library/detail.aspx?g=8b139876-7f92-4695-918b0e8262bf6621 (accessed 1 August 2021). In neighbouring Ireland, there is also a significant Right to Repair movement: see Karlin Lillington, 'The Growing Right-to-Repair Movement Tackling Throwaway Tech Culture' (The Irish Times, 29 July 2021), available at https://www.irishtimes.com/business/technology/the-growing-right-to-repair-movement-tacklingthrowaway-tech-culture-1.4633034 (accessed 1 August 2021).

${ }^{351}$ Leah Chan Grinvald and Ofer Tur-Sinai, 'Intellectual Property Law and the Right to Repair' (n 34).

352 CBC News, 'Canada Gets Closer to a Right to Repair Law' (1 March 2019), available at https://www.cbc.ca/news/technology/what-on-earth-newsletter-right-to-repair-styrofoam-1.5037697 (accessed 1 August 2021); Bill C-272 (n 151). For commentary, see Rosborough (n 151).

353 Dean Baker, Arjun Jayadev, and Joseph Stiglitz, Innovation, Intellectual Property, and Development: A Better Set of Approaches for the 21 ${ }^{\text {st }}$ Century (AccessIBSA 2017); Margaret Chon, Pedro Roffe and Ahmed Abdel-Latif (ed.) The Cambridge Handbook of Public-Private Partnerships, Intellectual Property Governance, and Sustainable Development (CUP 2018); Sara Bannerman, 'The World Intellectual Property Organization and the Sustainable Development Agenda' (2020) 122 Futures 102586; Rognstad and Ørstavik (n 297). 